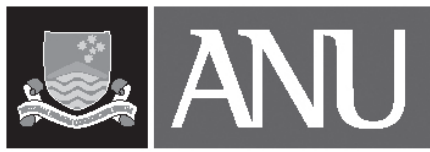

THE AUSTRALIAN NATIONAL UNIVERSITY

AUSTRALIA-JAPAN RESEARCH CENTRE

ANU COLLEGE OF ASIA \& THE PACIFIC

CRAWFORD SCHOOL OF ECONOMICS AND GOVERNMENT

\title{
IS FOREIGN AID A VANGUARD OF FOREIGN DIRECT INVESTMENT? A GRAVITY-EQUATION APPROACH
}

Hidemi Kimura and Yasuyuki Todo

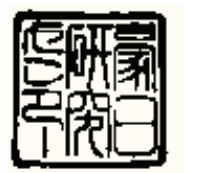

ASIA PACIFIC ECONOMIC PAPERS

No. 380, 2009 

ASIA PACIFIC ECONOMIC PAPER NO. 380

2009

\title{
Is Foreign Aid a Vanguard of Foreign Direct Investment? A Gravity-Equation Approach
}

\author{
Hidemi Kimura $^{\dagger}$ \\ and \\ Yasuyuki Todo ${ }^{\ddagger}$
}

AUSTRALIA-JAPAN RESEARCH CENTRE CRAWFORD SCHOOL OF ECONOMICS \& GOVERNMENT

ANU COLLEGE OF ASIA AND THE PACIFIC 
This work is copyright. Apart from those uses which may be permitted under the Copyright Act 1968 as amended, no part may be reproduced by any process without written permission.

Asia Pacific Economic Papers are published under the direction of the Editorial Committee of the Australia-Japan Research Centre (AJRC). Members of the Editorial Committee are:

Professor Jenny Corbett

Executive Director

Australia-Japan Research Centre

The Australian National University, Canberra

Professor Emeritus Peter Drysdale

Crawford School of Economics and Government

The Australian National University, Canberra

Professor Christopher Findlay

Professor of Economics

University of Adelaide

Adelaide, South Australia

Professor Stuart Harris

Department of International Relations

The Australian National University, Canberra

Dr Kazuki Onji

Crawford School of Economics and Government

The Australian National University, Canberra

Papers submitted for publication in this series are subject to double-blind external review by two referees. The views expressed in APEPs are those of the individual authors and do not represent the views of the Australia-Japan Research Centre, the Crawford School, or the institutions to which authors are attached.

The Australia-Japan Research Centre is part of the Crawford School of Economics and Government, The Australian National University, Canberra.

ISSN 07288409

ISBN 9780864133340

Australia-Japan Research Centre

Crawford School of Economics and Government

The Australian National University

Canberra ACT 0200

Telephone: (61 2) 61253780

FACSIMILE: (61 2) 61250767

E-MAIL: AJRC@ANU.EDU.AU

URL: HTTP://WWW.CRAWFORD.ANU.EDU.AU 


\title{
Is Foreign Aid a Vanguard of Foreign Direct INVESTMENT? A Gravity-Equation Approach ${ }^{1 *}$
}

\begin{abstract}
This paper investigates whether and how foreign aid facilitates foreign direct investment (FDI) flows into less developed countries. We employ a large data set of source-recipient country pairs and conduct gravity equation-type estimation. Our empirical methodology enables us to examine an effect through which aid from a donor country promotes FDI from the same donor in particular, which we call a 'vanguard effect.' We find that foreign aid in general does not have any significant effect on FDI. However, when we allow for differences in the size of aid effects across donor countries, we find robust evidence that foreign aid from Japan in particular has a vanguard effect, that is, Japanese aid promotes FDI from Japan but does not attract FDI from other countries.
\end{abstract}

Keywords: foreign aid; foreign direct investment; gravity equation

JEL classifications: F21; F35; O11

\section{Introduction}

Impacts of foreign aid to less developed countries (LDCs), particularly those on economic growth, have been examined recently to a great extent (Rajan and Subramanian 2005; Easterly and Levine 2003; Hansen and Tarp 2001; and Burnside and Dollar 2000; among many others). Foreign aid also possibly affects foreign direct investment (FDI) inflows to LDCs, since the purposes of aid for the donor country often include to encourage FDI to the recipient country of aid. For example, the OECD argues that foreign aid can improve investment environment and thus promote FDI (OECD 2004), and the US government explicitly states that a purpose of foreign aid is to encourage FDI (Congress of the United States 1997). ${ }^{1}$ The Japanese government also argues that a reciprocal relationship between FDI and aid helps the development of LDC economies (Arase 1994). Accordingly, the role of aid in promoting FDI has come to the fore in the policy discussion among government officials and development practitioners (OECD 2006).

There are a few studies which examine the relationship between foreign aid and FDI by using cross-country panel data, most notably Harms and Lutz (2006) and Karakaplan, Neyapti, and Sayek (2005). Harms and Lutz (2006) find that the effect of aid 
on FDI is generally insignificant but significantly positive for countries in which private agents face heavy regulatory burdens. Karakaplan, Neyapti, and Sayek (2005) also find an insignificant effect of aid on FDI, but in contrast to the finding of Harms and Lutz (2006), results of Karakaplan, Neyapti, and Sayek (2005) suggest that good governance and developed financial markets have a positive effect on aid. ${ }^{2}$

Both Harms and Lutz (2006) and Karakaplan, Neyapti, and Sayek (2005) use aggregate data on FDI and foreign aid for each recipient LDC. This paper extends these existing studies by using less aggregated data on FDI and aid, that is, data for each source-recipient country pair during the period 1990-2002. This country-pair dataset allows us to employ gravity equation-type estimation that is often used in recent studies on determinants of FDI such as Egger and Winner (2006), Mody and Razin (2003), Carr, Markusen, and Maskus (2001), and Wei (2000).

We presume that there are possibly multiple channels through which aid affects FDI, and the ambiguous effect of aid on FDI found in the existing studies may reflect the amalgamation of positive and negative effects of aid. These channels include a positive 'infrastructure effect' by improving economic and social infrastructure in the recipient country, a negative 'rent-seeking effect' by encouraging unproductive rent-seeking activities, both of which are suggested by Harms and Lutz (2006); a positive 'financing effect' by improving the ability of the recipient country to finance outflows of profit repatriation from FDI; and a negative 'Dutch-disease effect' by distorting resource allocations between tradable and non-tradable sectors (Arellano et al. 2009).

In addition to these effects of aid, this paper proposes that aid has a positive 'vanguard effect,' through which foreign aid from a particular donor country promotes FDI from the same donor country but not from other countries. For example, if aid for infrastructure from Japan to Thailand facilitates FDI flows from the United States to Thailand, this might be because the Japanese aid has an infrastructure effect. However, if aid from Japan to Thailand promotes FDI from Japan in particular, without affecting FDI from other countries, we conclude that the Japanese aid has a vanguard effect.

There may be several reasons for this vanguard effect. First, when foreign aid is provided, information on the local business environment of the recipient country can be exclusively transmitted to firms of the donor country. Second, the fact that the government provides aid may reduce the recipient country's investment risks as perceived subjectively by firms of the donor country. Third, aid may bring donor country-specific business practices, rules, and institutions into recipient countries. Those effects of foreign aid should promote FDI from the same donor country, but do not necessarily promote FDI from other countries. 
We isolate the vanguard effect of aid from other effects by estimating the effect of aid from a particular donor country, rather than the total aid from all donor countries, on FDI from that donor. It should be emphasised that the use of country-pair data enables us to investigate the vanguard effect, and thus the distinction of the vanguard effect of aid on FDI from other effects is a major contribution of this paper. Empirical investigation of the vanguard effect is important in practice, since aid is often motivated by the donor country's willingness to encourage FDI from the donor, as we noted earlier.

In addition, we distinguish between aid for infrastructure and aid for other purposes in order to examine possible differences in the size of aid effects between the two types of aid, since the two types may influence each type of effect of aid differently, as explained earlier. The distinction between these two types of aid has also not been analysed in previous studies.

To preview the results, we find that foreign aid in general does not necessarily promote FDI, a result consistent with Harms and Lutz (2006) and Karakaplan, Neyapti, and Sayek (2005). We also find that neither aid for infrastructure nor non-infrastructure has any significant impact on FDI. As to the final role of foreign aid on FDI, namely the vanguard effect, we find no general evidence of such an effect. We then further examine possible differences in the size of the impact of aid among donor countries. Our results show that foreign aid for infrastructure from Japan has a vanguard effect, while the effect of aid from all other countries on FDI seems to be absent. In other words, infrastructure aid from Japan promotes FDI from Japan to the recipient country of aid, while having no impact on FDI from other countries to the recipient. ${ }^{3}$ The size of the vanguard effect for Japanese aid is large, since our results imply that six per cent of Japanese FDI in East Asia during the period 1990-2002 is attributed to Japanese aid.

The rest of the paper is organised as follows. Section 2 specifies the econometric model, whereas Section 3 describes the data and variables. Section 4 shows the estimation results, which is followed by concluding remarks in Section 5 .

\section{The Econometric Model}

\section{(a) Estimation equation}

To estimate the impact of foreign aid on FDI, we incorporate foreign aid variables to gravity equation-type regression. Our gravity-equation framework can be regarded as an extension of Harms and Lutz (2006) and Karakaplan, Neyapti, and Sayek (2005), who examine the impact of foreign aid on FDI by employing the total amount of aid from all donor countries to each recipient country as the key independent variable and the 
total amount of FDI inflows to the recipient as the dependent variable. In contrast, our gravity-equation framework allows us to use foreign aid and FDI between each sourcerecipient country pair for estimation.

In particular, we employ a simplified version of econometric specifications used in Egger and Winner (2006) and Carr, Markusen, and Maskus (2001) that are based on the knowledge-capital (KK) model developed in Markusen (2002). The KK model suggests that the size of the host country's economy should positively affect the extent of horizontal multinationals that produce their products for the host-country market, whereas the size of the home country's economy should positively affect the extent of vertical multinationals that export their products to the home-country market. ${ }^{4}$ The KK model also suggests that a larger difference in skilled labour abundance between the home and the host country provides a greater incentive for firms in the home country to relocate labour-intensive production processes to the host country and hence raises the extent of vertical FDI. In addition, following Egger and Winner (2006), Mody, Razin, and Sadka (2003), and Wei (2000), we assume that geographic distance between the home and host country impedes FDI flows.

These arguments above, and our further presumption that FDI flows are persistent, lead to the following dynamic gravity equation to estimate the determinants of FDI:

$$
\begin{aligned}
\ln F D I_{i j t}= & \rho \ln F D I_{i j, t-1}+\beta_{1} \ln A I D_{j, t-1}+\beta_{2} \ln G D P_{i, t-1}+\beta_{3} \ln G D P_{j, t-1}+\beta_{4} \ln D I S T_{i j} \\
& +\beta_{5} S K D I F_{i j, t-1}+\beta_{6} S K D I F_{i j, t-1}^{2}+\alpha_{i j}+\alpha_{t}+\varepsilon_{i j t},
\end{aligned}
$$

where subscripts $i, j$, and tenote respectively the source and the recipient country of FDI and foreign aid and the time period. The dependent variable, lnFDIijt, is the logarithm of the inflows of $\mathrm{FDI}^{5}$ from country $i$ to $j$ at time $t$, whereas our key independent variable, $\ln$ AIDij,t- 1 , is the log of the real value of foreign aid flows from country $i$ to $j$ at time $t-1$. As we will explain below, we will experiment with several alternative measures of foreign aid for estimation. We take the first lag of foreign aid to incorporate possible time lags between the provision of aid and the decision on FDI. Using the first lag also alleviates possible endogeneity due to simultaneity, although we correct for such endogeneity by using instruments as we will explain later. GDPi and GDPj represent GDP of country $\mathrm{i}$ and $\mathrm{j}$, respectively, DISTij the geographic distance between $\mathrm{i}$ and $\mathrm{j},{ }^{6}$ and SKDIFijt a measure of skilled-labour abundance in country i relative to $\mathrm{j}^{7} \mathrm{ij}_{\mathrm{j}} \mathrm{t}$, and ijt are country pair-specific fixed effects, year-specific effects, and an error term, respectively.

\section{(b) How does foreign aid affect FDI?}

Harms and Lutz (2006) argue that foreign aid has two effects on FDI flows. On the one hand, foreign aid improves the recipient country's infrastructure, including 'encompass- 
ing roads, telephone lines and electricity as well as less measurable items like education or a reliable and well-functioning bureaucracy,' (an earlier version of Harms and Lutz, 2006) and hence raises the marginal product of capital in the country. Therefore, foreign aid encourages FDI inflows to the recipient country of aid. We label this positive effect of aid as the 'infrastructure effect'.

On the other hand, Harms and Lutz (2006) also argue that foreign aid may encourage unproductive rent-seeking behaviours in the recipient country, leading to a drop in productivity. For example, when aid is provided, private firms might engage more in competition for rents from the aid and less in activities for improving their productivity such as training and R\&D activities. Consequently, provision of foreign aid may reduce the marginal product of capital of the recipient and thus discourage FDI inflows to the recipient. We refer to this negative effect as the 'rent-seeking effect'. ${ }^{8}$

Several other possible effects of aid on FDI can be identified. For example, provision of aid, program aid in particular, improves the balance of payments, expanding the ability of the recipient country of aid to finance sustainable outflows of profit repatriation from FDI. Through this 'financing effect', aid may encourage FDI. Also, Arellano et al. (2009) point to a 'Dutch disease' effect of aid. Aid is likely to increase the supply of tradables and hence to lower their price relative to non-tradables. Since FDI in LDCs is mostly invested in tradable sectors, aid may discourage FDI through this channel which distorts the allocation of domestic resources. ${ }^{9}$

In addition to these effects suggested in existing studies, this paper proposes another effect of foreign aid on FDI, a positive effect through which foreign aid from a particular donor country promotes FDI from the same country but not from other countries. Since foreign aid acts as a 'vanguard' of FDI in this case, we refer to this effect as the 'vanguard effect' of aid.

We presume that this vanguard effect can be generated through the following three channels. First, Mody, Razin, and Sadka (2003) theoretically suggest and empirically find that information on the host economy should play a significant role in driving FDI flows, since FDI is risky to investors. However, information on the business environment of the host country, such as the skill level of local labour, conditions of infrastructure, the quality of bureaucrats, and explicit and implicit business rules and government regulations, is often inaccessible to foreign firms. Nevertheless, by engaging in activities funded by foreign aid, firms and government agencies of the donor country can obtain such information on the recipient country, and this information may spill over to other firms of the donor country. Second, the fact that the government provides foreign aid may reduce investment risks perceived subjectively by firms investing in the recipient country. Suppose, for example, a financial crisis like the Asian financial crisis of 1997 hits an LDC. Then, donor countries 
of aid to the country in trouble have larger incentives to bail out the recipient country than other countries without aid, since the provision of aid may reflect strong ties with the recipient country. Therefore, aid provides a quasi government guarantee to private firms and thus encourages FDI. Third, foreign aid from a donor country sometimes introduces to the recipient country business practices, rules, and systems of the donor country. If the donor's business systems become the de facto standard in the recipient country, the standard is likely to promote FDI from that donor country in particular.

It should be emphasised that through this vanguard effect, foreign aid from donor country $i$ to recipient country $j$ should promote FDI flows from country $i$ to $j$, but not FDI from other countries to country $j$. In this regard, the vanguard effect is different from other effects, such as the infrastructure, rent-seeking, financing, and Dutch-disease effects, through which foreign aid by donor country $i$ to recipient $j$ should affect FDI from any country to $j$.

To estimate the effects of foreign aid that are not country-pair specific, such as the infrastructure and rent-seeking effects, we first employ the total amount of foreign aid from all member countries of OECD's Development Assistance Committee (DAC), i $A I D_{i j}$. However, we would expect that each of these effects of aid varies in size depending on the type of aid, particularly between aid for infrastructure and non-infrastructure. For example, the infrastructure effect works more in the case of infrastructure aid than in the case of non-infrastructure aid, while the financing effect works the opposite way. The rent-seeking effect may be associated with aid for both infrastructure and non-infrastructure. Distinguishing the effect of aid for infrastructure from the effect of aid for non-infrastructure is not easy in practice, since aid is fungible, that is aid for non-infrastructure may lead to an increase in the recipient government's spending on infrastructure and vice versa. Despite this difficulty, we distinguish between aid for infrastructure $\left(\Sigma_{i}\right.$ $\left.A I D_{-} I N F_{i j}\right)$ and for non-infrastructure $\left(\sum_{i} A I D_{-} N o n I N F_{i j}\right)$ and estimate the impact of each type of aid on FDI to see any possible differences between the two types of aid.

To distinguish the country pair-specific vanguard effect from other effects, we next examine the effect of foreign aid from the home country of FDI, or country $i$, to the host country $j$, rather than the total foreign aid from all donor countries as used before. Under the vanguard hypothesis, infrastructure and non-infrastructure aid from country $i$ to $j, A I D \_I N F_{i j}$ and $A I D_{-} N_{N o n I N F}$, respectively, has a positive effect on FDI from $i$ to $j$ but no effect on FDI from other countries. The size of the effect of infrastructure and non-infrastructure aid may be different from each other, depending on how each type of aid promotes FDI through the three channels of the vanguard effect explained earlier. $A$ priori, both types would raise the extent of the quasi government guarantee through aid, while information spillovers and transfer of country-specific business rules would work 
No. 380, 2009

more in the case of infrastructure aid.

\section{(c) Estimation method}

We employ two types of estimation method. We start with ordinary least squares (OLS) estimation without fixed effects using robust standard errors adjusted for correlations within each country pair. The OLS estimators are consistent only when all regressors are orthogonal to the error term. However, there are two reasons why the orthogonality assumption may not hold in our FDI regression. First, as Egger $(2005,2002)$ argues, the error term may include unobserved country pair-specific effects that are correlated with regressors employed. Second, some of the regressors, such as foreign aid variables and GDP, are likely to be correlated with shocks that affect FDI. Many existing studies estimating income-growth regression on foreign aid argue possible simultaneity biases due to endogeneity of foreign aid variables and in fact find that OLS estimators are very different from estimators correcting for endogeneity Roodman (2007), Hansen and Tarp (2001), Burnside and Dollar (2000), and Boone (1996). It is highly possible that foreign aid variables are also endogenous in FDI regression, since income growth and FDI flows are likely to be determined simultaneously.

Therefore, in order to correct for biases arising from country pair-specific fixed effects and endogeneity, we employ the system generalised method of moments (GMM) estimation developed by Blundell and Bond (1998). In the system GMM estimation, we apply GMM estimation to the system of equation (1) and its first-difference in which the country pair-specific fixed effects are eliminated, using the first-lagged and first-differenced regressors as instruments for equation (1) and the second lagged regressors as instruments for the first-differenced equation. The lagged regressors can be used as instruments, since they are predetermined and thus should not be correlated with the contemporaneous error term. The major advantage of the system GMM estimation, compared with its predecessor, the difference GMM developed by Arellano and Bond (1991), is that in the latter, instruments are weak if regressors have near unit root properties, whereas this problem can be alleviated in the former. We apply the two-step procedure to the system GMM estimation to obtain larger efficiency. In addition, we use Windmeijer's (2005) methodology to obtain robust standard errors. The estimator thus obtained is consistent even in the presence of heteroskedasticity and corrects for finite sample biases found in the two-step estimations. We test whether instruments are orthogonal to the error term using the Hansen $j$ statistic and whether the error term is auto-correlated using the Arellano-Bond statistic. ${ }^{10}$ 


\section{Data}

Our sample consists of country pairs during the period 1990-2002, although data for the period 1985-1989 are used as instruments in the system GMM estimation. We limit source countries to the top five donor countries (France, Germany, Japan, the United Kingdom, and the United States $)^{11}$, which contribute to around 70 per cent of the total aid from OECD countries, and recipient countries to low- or middle-income countries according to the World Bank's classifications in 1990. In addition, since we use first-differenced FDI flows as a dependent variable and second-lagged FDI flows as an instrument in the system GMM estimation, we limit observations for which the first and second lags of FDI flows are available. Accordingly, our estimation is based on unbalanced panel of 1,384 observations and 227 country pairs which include 98 recipient countries. ${ }^{12}$ The total amount of foreign aid in our sample consists of 42 per cent of the total amount of aid provided in the whole world during the same period.

Our dependent variable $\ln F D I_{i j t}$ is the natural logarithm of FDI flows from country $i$ to LDC $j{ }^{13}$ The amount of FDI flows for each home-host country pair is represented by gross FDI outflows from country $i$ to $j$ reported by country $i$, taken from OECD's International Direct Investment Statistics (available at http://miranda.sourceoecd.org/). ${ }^{14}$ To construct real FDI, nominal FDI flows are divided by the GDP deflator of the host country, for which the base year is 2000, taken from World Bank's World Development Indicators 2006 (WDI). We add one before taking a log of real FDI flows. ${ }^{15}$

Data on bilateral foreign aid are taken from the OECD's Creditor Reporting System (CRS) that provides detailed information on each activity funded by foreign aid. ${ }^{16}$ In particular, we aggregate the committed amount ${ }^{17}$ of bilateral foreign aid funded to each activity to construct the total inflows of foreign aid from donor country $i$ to recipient country $j$ in year $t$. We exclude from our foreign aid variables foreign aid activities coded as 900 in the CRS dataset. Aid of code 900 is excluded since this class of aid includes 'administrative costs of donors' and 'spending in the donor country for heightened awareness/interest in development co-operation' that are not spent in the recipient country. Using the data on foreign aid flows deflated by the GDP deflator of the recipient country, we construct real foreign aid from country $i$ to country $j$ in year $t, A I D_{i j t}$, and the total foreign aid from all donor countries to country $j,{ }_{i} A I D_{i j t}{ }^{18}$

In addition to the total amount of bilateral foreign aid, we distinguish between foreign aid for infrastructure and for non-infrastructure to highlight possible differences between the two types of aid. Since Harms and Lutz (2006) suggest that 'infrastructure' should be broadly defined and include economic and social infrastructure, we define foreign aid for infrastructure as the sum of foreign aid for 'social infrastructure,' 'economic infrastructure,' 'production activities,' and 'multi-sector/cross-cutting' classified in the 
CRS dataset. Aid for social infrastructure (coded as 100 in the CRS dataset) includes aid related to education and health, whereas aid for economic infrastructure (200) is for transport, energy, and financial services. Aid for production activities (300) is mostly for the agriculture, manufacturing, and mining industries, and multi-sector aid (400) is a mixture of those types of aid.

In contrast, foreign aid for non-infrastructure is defined as the sum of 'commodity aid and general program assistance' (500), 'action relating to debt' (600) and 'humanitarian aid' (700). The large part of the 'commodity aid' is food aid, whereas the 'general program assistance' corresponds to general budget support and does not include sectorspecific program assistance that is categorised as multi-sector aid. Aid for 'action relating to debt' is mostly spent on debt forgiveness. The 'humanitarian aid' is defined as assistance during and in the aftermath of emergencies. We take a log of these aid variables, after adding one, ${ }^{19}$ to create our key regressors related to foreign aid.

Real GDP and real GDP per capita of the source and the recipient country of aid are taken from WDI. The measure of the relative skill level of the source country to the recipient is defined as the difference between the log of real GDP per capita of the two countries. ${ }^{20}$ Distance between two countries is defined as the distance between the capital cities of these countries and constructed from the longitude and latitude of the two cities taken from the NIJIX's web site (http://www.nijix.com).

In addition to the benchmark estimations, we also follow Harms and Lutz (2006) and Karakaplan, Neyapti, and Sayek (2005) and examine the relation between the level of governance and the size of the impact of aid. In these estimations, we use two governance indicators taken from Kaufmann and Kraay (2006). In particular, we use the index of the regulatory quality denoted as Kaufmannl, following Harms and Lutz (2006), or the sum of six indices for the level of voice and accountability, the political stability, the government effectiveness, the regulatory quality, the rule of law, and the control of corruption denoted as Kaufmann2, following Karakaplan, Neyapti, and Sayek (2005). Our governance indices are normalised so that the minimum is 0 with a higher score indicating a higher level of governance. ${ }^{21}$

Table 1 presents summary statistics of the dependent and independent variables used in the estimation. 


\section{Estimation Results}

\section{(a) Results assuming no difference across donor countries}

We start with the estimation of the impact of foreign aid on FDI, using the total aid from all donor countries to each recipient country, i AIDij, as the key independent variable. The OLS and GMM results are presented in columns 1 and 2 of Table 2, respectively. The $\mathrm{p}$ value of the Hansen J statistic and the Arellano-Bond statistic shown in the last two rows implies that the instruments are orthogonal to the error term and that the error term is not auto-correlated in the system GMM estimation. Since this is the case for all the system GMM estimations below, we will rely more on the GMM results than the OLS results. According to the GMM results in column 2 of Table 4, the effect of the total aid from all donor countries to country $j$ on FDI from country $i$ to $j$ is positive but statistically insignificant. This evidence suggests that the total effect of foreign aid on FDI is not substantial.

Results on other control variables are mostly consistent with the theoretical prediction. The source and the recipient country's GDP have a positive and significant effect on FDI, supporting the prediction of the KK model of multinationals. Geographic distance affects FDI negatively and significantly, supporting our gravity-type specification. The effect of the relative skill level of the home country to the host, SKDIF, is negative and significant, while the effect of its square is positive and significant. ${ }^{22}$ These results suggest that the effect of the relative skill level is U-shaped. In light of the KK model's prediction that a large difference in the skill level between the developed home country and the less developed host country facilitates vertical FDI, the results are consistent with this prediction for relatively poor LDCs. Our finding that the amount of FDI is large when the skill difference is very small may reflect another theoretical argument of the KK model that similarity in the skill level between the home and the host country promotes horizontal FDI when transportation costs are low. Since these results on other control variables will hold in most specifications below, we will henceforth focus on results on foreign aid variables.

Next, we follow Harms and Lutz (2006) and Karakaplan, Neyapti, and Sayek (2005) and test whether the quality of governance of the recipient country affects the effect of foreign aid on FDI by including the interaction term between aid flows and an index of governance taken from Kaufmann and Kraay (2006). As the governance index, we use either the index for regulatory burden (Kaufmanl), which is found to affect the size of the aid effect by Harms and Lutz (2006), or the sum of the six indices of governance (Kaufman2) used in Karakaplan, Neyapti, and Sayek (2005). The OLS and GMM results 
are reported in columns 3-6 of Table 2. Note that since the indices of governance are available from 1995, the sample size is smaller than in the estimation in columns 1 and 2 of Table 2. In any specification, we find that the coefficient on aid and its interaction with the governance index is insignificant. The difference in estimation results between the existing studies and this paper probably comes from the difference in the data-sets used: the data-sets used in Harms and Lutz (2006) and Karakaplan, Neyapti, and Sayek (2005) are based on data for each recipient country, while our data-set is based on data for each source-recipient country pair. In any case, the two existing studies and this paper reached results contradicting one another, and thus whether the quality of governance affects the effect of foreign aid on FDI may be unclear.

Next, we distinguish between infrastructure and non-infrastructure aid and examine whether each type of aid promotes FDI. As we discussed earlier, there are several potential effects of aid on FDI, such as the infrastructure, rent-seeking, financing, and Dutch-disease effects, and each effect differs in that it works in the case of infrastructure or non-infrastructure aid or both. Therefore, the effect of each type of aid may differ. The OLS and GMM results from using both aid for infrastructure and non-infrastructure are reported in columns 1 and 2 of Table 3, respectively. The OLS and GMM results show that the effect of both aid for infrastructure and for non-infrastructure is insignificant. We further test whether the difference in size between the effects of the two types of aid is zero by a Wald test. The $\mathrm{p}$ value of the Wald test is 0.83 in the OLS estimation and 0.31 in the GMM, suggesting no difference. ${ }^{23}$

Since the two types of aid stock are correlated, ${ }^{24}$ standard errors in models 1 and 2 of Table 3 may be overestimated due to multi-collinearity. We thus estimate the effect of each of the two types of aid separately, but our OLS and GMM estimation again leads to insignificant effect of aid for infrastructure and non-infrastructure (columns 3-6 of Table 3).

Furthermore, in order to highlight the vanguard effect through which foreign aid from a donor country promotes FDI from the donor but not from other countries, we regress bilateral FDI flows on aid from the home country of FDI in particular, AIDij, rather than total aid from all donor countries, i AIDij, as we used above. The GMM results reported in column 1 of Table 4 indicate that foreign aid has no significant effect on FDI from the donor country. This is the case even when we distinguish between aid for infrastructure and non-infrastructure (columns 2-4 of Table 4 ). This evidence rejects the presence of the vanguard effect of aid.

In summary, our results suggest that foreign aid does not promote FDI. ${ }^{25}$ However, we have so far assumed that the effect of foreign aid on FDI does not vary in size across donor countries. This assumption may not hold in practice, since objectives, methods, and 
modality of foreign aid vary substantially across donors. Therefore, in the next subsection we will relax this assumption.

\section{(b) Results assuming possible differences across donor countries}

We now examine possible differences in the size of the aid effect across donor countries. First, we estimate the effect of foreign aid from each of the five donor countries on FDI to the recipient country of aid and show the GMM results in Table 5. In the table, subscripts $F R, G M, J P, U K$, and US denote France, Germany, Japan, the United Kingdom, and the United States, respectively. Thus, for example, $\ln A I D_{F R, j}$ in the first row denotes the log of aid from France to country $j$. The dependent variable is still the log of FDI flows from country $i$ to $j$, as before. Thus, the result in the row of $\ln A I D_{F R, j}$ indicates the effect of aid from France on FDI from any country to the recipient country of the French aid.

Column 1 of Table 5 reports GMM results without distinguishing between aid for infrastructure and non-infrastructure. The GMM results indicate that aid from any particular donor country has no significant impact on FDI at the five-per cent level. In addition, we examine the effect of aid for infrastructure and non-infrastructure separately, employing both types together (column 2), only aid for infrastructure (column 3), or only aid for non-infrastructure (column 4), and we again find no effect of aid in most cases. Although the effect of aid for infrastructure from the United States is negative and significant at the 10 -per cent level in column 2 , it is insignificant in column 3 . Similarly, although the effect of non-infrastructure aid from the United States is insignificant in column 2, it is negative and significant at the five-per cent level. Therefore, the negative effect of US aid found in some specifications is not robust, and it is not clear whether US aid has in fact a negative impact on FDI.

It should be noted that the $p$ value of the Hansen $J$ statistic is very close to 1 in columns $1-3$ of Table 5. According to Roodman (2007), a high $p$ value is obtained when there are too many instruments, and in that case the Hansen $J$ test is weak. However, since we have found in Table 3 that the lagged foreign aid variables are orthogonal to the error term, the lagged foreign aid variables for each donor country used in Table 5 as instruments are also likely to be orthogonal to the error term. Therefore, we conclude that biases due to too many instruments may not be large in the GMM estimations in Table 5 .

We further estimate the effect of foreign aid from each of the five donor countries on FDI from the donor country of aid and present the results in Table 6. This is different from the estimation performed just above (Table 5 ) in that we are now testing the vanguard effect of aid from each donor. For this purpose, we use as regressors $\ln A I D_{F R, j}$ $\times F R_{j}$ and corresponding interaction terms for other donors, where $F R_{j}$ is a dummy vari- 
able which is one if the home country of FDI, or country $i$, is France and zero otherwise. Since $\ln A I D_{F R, j} \times F R_{j}$ is zero unless the source country of FDI is also France, this can test the vanguard effect of French aid.

The GMM results reported in column 1 of Table 6 indicate that aid from Japan has a positive and significant (at the five-per cent level) effect on FDI particularly from Japan, whereas aid from the United States has a negative effect. When we use aid for infrastructure and non-infrastructure separately as regressors (columns 2-4), we find a significant effect in the case of Japanese aid for infrastructure (columns 2 and 3 ) that is similar in size to the effect of Japanese aid of all types (column 1). In contrast, the effect of Japanese aid for non-infrastructure is insignificant in columns 2 and 4 at the five-per cent level. The negative effect of US aid becomes insignificant at the five-per-cent level when we distinguish between the two types of aid, suggesting that these results are not robust to alternative specifications. ${ }^{26}$ Therefore, only the positive effect of Japanese aid for infrastructure is robust and significant in our estimation.

Since the $p$ value of Hansen $J$ statistics in Table 6 is 1.000 , or close to one as in Table 5 , there may be a problem of too many instruments again. To avoid these possible biases, we drop the aid variables except for that of Japan to lower the number of regressors and thus the number of instruments. Although we do not show the results from this modification for reasons of brevity, we find no substantial change in the effect of Japanese aid compared with the results in Table 6 . The $p$ value of the Hansen $J$ statistic is about 0.2 , indicating that there are not too many instruments in those GMM estimations.

This evidence on Japanese aid, combined with the previous evidence found in Table 5 that aid from Japan does not promote FDI in general, supports the vanguard hypothesis of foreign aid in the case of Japanese aid. In other words, while foreign aid has no effect on FDI in general, foreign aid from Japan in particular is likely to promote FDI from Japan. However, this positive effect of Japanese aid is limited to FDI from Japan: that is, Japanese aid has no effect on FDI from other countries.

The size of the vanguard effect of Japanese aid is quantitatively large. The average of the $\log$ of FDI flows from Japan to the six East Asian countries in our sample (China, the Republic of Korea, Indonesia, Malaysia, the Philippines, and Thailand) is 13.2, whereas the average of the log of foreign aid for infrastructure from Japan to these countries is 12.7. Using the coefficient of the Japanese aid in column 3 of Table 6, 0.064, we conclude that six per cent $(=0.064 \times 12.7 / 13.2)$ of Japanese FDI in East Asia is attributable to the presence of Japanese aid. 


\section{(c) Robustness checks}

In the previous section, we examined the relation between FDI flows and the previous year's foreign aid flows, using annual data. A shortcoming of this specification is that we ignore the impact of foreign aid provided more than two years before on current FDI flows. This shortcoming may be serious when we examine the infrastructure effect of aid, since infrastructure previously built using foreign aid would attract FDI in the long run. Another shortcoming is that the key variables in the gravity model, such as FDI and GDP, fluctuate annually to a large extent according to business cycles. Foreign aid is also found volatile (Bulir and Hamann 2008). Such fluctuations may lead to a bias in the estimation, although we alleviated the possible biases by incorporating year dummies and employing the system GMM procedure. In addition, annual data may be contaminated by time-series correlation in the dependent and independent variables. Although the use of the dynamic panel GMM estimation alleviates the problem of non-stationarity (Yao 2006), the vanguard effect of Japanese aid found earlier may still have reflected a spurious relation between FDI and aid if the FDI and aid variables have unit-root properties.

To alleviate these potential problems, we re-estimate the aid-FDI nexus using data based on three-year averages. More specifically, we divide the 18 -year period from 1985 to 2002 to six three-year periods and average all the variables used in the previous estimations over the three years. Since we take first differences and use second lagged independent variables as instruments in the system GMM estimation, we have four periods for the estimation. By using the three-year averages, we can incorporate a longer-term effect and reduces effects of volatility. In addition, since the dynamic GMM can be applied when the number of time periods is small compared with the number of cross-section units (Bond 2002), the dynamic GMM estimation using the shorter panel based on the three-year averages performs better in order to alleviate biases due to non-stationarity.

Tables $7-8$ show the results using the three-year averages. To save space, we only show several representative results corresponding to the benchmark results in Tables 2-6. The results in Table 7 indicate that foreign aid has no significant effect on FDI in any specification when we assume that the aid effect does not vary in size among donor countries. In addition, column 3 of Table 8 indicates that aid for infrastructure from Japan and the United Kingdom has a positive and significant effect on FDI from the donor country, while the results on the donor country-specific effect of aid for other donors are not significant.

In addition, as another robustness check, we focus on poorer countries as recipient countries. Although our sample has so far included middle- and low-income countries, some of which are relatively advanced, we now use the sub-sample for countries that are defined as lower-middle or low income countries in 1990 by the World Development 
Indicators and repeat the same regressions as in Tables 2-6. Since the results are qualitatively the same as the benchmark results presented in Tables $2-6$, Table 9 show only the results corresponding to those in column 1 of Tables 5 and 6 . Column 2 of Table 9 clearly indicates that Japanese aid has a positive vanguard effect, while aid from other countries has no vanguard effect. Since the coefficient on the Japanese aid is more than twice as large as that using the whole sample, we conclude that the vanguard effect of Japanese aid is even larger for poorer countries.

In summary, these results using three-year averages and using the LDC sample are mostly consistent with the benchmark results using annual data. In particular, results from all specifications indicate that Japanese aid for infrastructure has a positive and highly significant effect on FDI from Japan. By contrast, effects which are significant in some specifications, such as a negative effect of US aid (Table 6) and a positive vanguard effect of UK aid (Table 8), are not robust to alternative specifications, leading to a doubt about the presence of those effects.

\section{(d) Why is Japanese aid so unique?}

According to the findings above, we conclude that foreign aid from any donor country has no infrastructure or rent-seeking effect on FDI. Aid from Japan has a vanguard effect, promoting FDI from Japan, while aid from other countries has no vanguard effect. This evidence emphasises a distinct feature of Japanese aid compared to aid from other countries. Now the remaining question is: why is Japanese aid so unique? In this subsection, we introduce some discussion about the characteristics of Japanese foreign aid.

One may hypothesise that the focus of Japanese aid on economic infrastructure may have induced its vanguard effect. In fact, Japan spent more than 50 per cent of its total aid on economic infrastructure in 2002, while other top donors spent less than 15 per cent on that type of aid. Thus, the positive impact of Japanese aid on Japanese FDI we found may have picked up a positive effect of aid for economic infrastructure. To test this hypothesis, we regress FDI on aid for economic infrastructure from the home country of FDI and other benchmark regressors, but we do not find any significant effect of aid for economic infrastructure. ${ }^{27}$

Another possibility is related to the degree of 'tied' aid in which procurement of the goods and services involved is limited to the donor country. Some may argue that since Japanese aid is often tied, it is not surprising that Japanese aid promotes Japanese FDI. However, this is not the case for two reasons. First, while tied aid does promote purchases from the donor country, or exports from the donor, it does not necessarily promote FDI inflows from the donor, or investment in the recipient country for long-term purposes. Second and more importantly, the share of tied aid in total aid for Japan is in fact low: 
it was 15 per cent in 1990 and 9 per cent in 2002, lower than the average share for all DAC countries, 32 and 11 per cent, respectively DAC (2007). The low share of tied aid in the case of Japan comes mostly from the fact that a large proportion of Japanese aid is loans which cannot be tied aid by agreement among DAC countries.

Then, what are the characteristics of Japanese aid that promote Japanese FDI? Above all, we should note that the Japanese government has indeed intended to promote FDI from Japan through foreign aid, particularly in East and Southeast Asia where Japanese firms have developed production and trade networks. This intension of the Japanese government has been emphasised in a number of articles including Kawai and Takagi (2004), DAC (2003), and Arase (1994).

In practice, the Japanese government employs a number of measures to promote FDI through aid. Most notably, when Japanese aid is provided, there is close coordination between the public and private sectors through, for example, participation of representatives of the private sector in government committees on foreign aid and exchange of personnel between aid agencies and private firms Arase (1994).

Such close inter-action between the public and private sectors should lead to spillovers of information on the recipient country's business environment to private firms through foreign aid, encouraging FDI. In addition, private firms can easily propose aid projects that facilitate implementation of business standards, rules, and systems specific to Japanese firms, such as kaizen ${ }^{28}$. The Japanese government in fact provides technical assistance to teach such Japanese business systems and funds to transplant certification systems for management and engineering skills developed and used in Japan. Those types of aid are likely to promote Japanese FDI but not the FDI of other countries. Furthermore, due to the close interaction between public and private sectors in Japan, the fact that the Japanese government provides foreign aid to a particular country should reduce that recipient country's risks as perceived subjectively by Japanese firms. ${ }^{29}$

Through these channels, the vanguard effect of Japanese aid is likely to be purposely generated by the close interaction between public and private sectors.

\section{Concluding Remarks}

This paper investigates whether and how foreign aid facilitates FDI flows into LDCs, applying data for each source-recipient country pair to gravity equation-type estimation. Our empirical methodology enables us to distinguish between standard effects of aid, including the infrastructure, rent-seeking, financing, and Dutch-disease effects, and the vanguard effect through which aid from a donor country promotes FDI from the donor in particular. Possible reasons for the vanguard effect are that aid could transmit tacit 
information on the business environment of the recipient country, reduce country risk with the provision of a quasi government guarantee, and set donor country-specific business standards in advance of private investment. Our results indicate that foreign aid in general does not necessarily have a significant effect. However, when we allow for differences in the size of aid effects across donors, we find robust evidence that infrastructure aid from Japan has a vanguard effect. In other words, Japanese aid promotes FDI from Japan, while having no impact on FDI from other countries.

Our results may lead to two opposing views toward Japanese aid. On the one hand, since existing studies found a possible link between FDI and income growth under certain conditions, ${ }^{30}$ our results imply that Japanese aid may have helped at least some of its recipient countries raise their income level indirectly by encouraging Japanese FDI to the recipients. This view is in fact supported by the Japanese government, which argues that provision of a 'trinity,' the combination of FDI, trade, and aid, is helpful in developing LDCs economies (Arase 1994) and hence that Japanese FDI promoted by aid is beneficial not only to Japanese firms but also to LDCs. Based on this argument, the Ministry of Economy, Trade and Industry (METI) of Japan advocates experiences of Japan's economic cooperation in East Asia as the successful 'Japan's ODA (official development assistance) model' (METI 2006). On the other hand, the same results can suggest that Japanese aid is aimed at provision of business opportunities to Japanese firms, rather than reduction of poverty in LDCs. So a possible policy implication from the empirical evidence is that the Japanese government should modify the focus of Japanese aid toward more direct channels of poverty alleviation.

Unfortunately, however, the present paper cannot clearly indicate which view fits the actual role of Japanese aid in economic growth in LDCs, since our analysis is limited to the aid-FDI nexus and does not cover the aid-growth nexus through FDI. We expect that future studies can fill the missing link between the aid-FDI nexus and the FDI-growth nexus.

Finally, an important caveat of this study should be mentioned. In this study, we incorporated differences in aid effects between donors and between aid for infrastructure and non-infrastructure. However, aid effects may depend on other factors, such as economic and social conditions of the recipient country, and modality and volatility of aid. These issues are beyond the scope of this paper and should be examined in further studies. 


\section{References}

Arase, D., 1994. 'Public-private sector interest coordination in Japan's ODA', Pacific Affairs, 67(2):171-199.

Arellano, M. and Bond, S., 1991. 'Some tests of specification for panel data: Monte Carlo evidence and an application to employment equations', Review of Economic Studies, 58(2):277-297.

Arellano, C., Bulir, A., Lane, T., and Lipschitz, L., 2009. 'The dynamic implications of foreign aid and its variability', Journal of Development Economics, 88(1):87-102.

Bergstrand, J. and Egger, P., 2007. 'A knowledge-and-physical-capital model of international trade flows', foreign direct investment, and multinational enterprises, Journal of International Economics, 73(2):278-308.

Blaise, S., 2005. 'On the link between Japanese ODA and FDI in China: A micro economic evaluation using conditional logit analysis', Applied Economics, 37(1):51-55.

Blundell, R. and Bond, S., 1998. 'Initial conditions and moment restrictions in dynamic panel data models', Journal of Econometrics, 87(1):115-143.

Bond, S., 2002. 'Dynamic panel data models: a guide to micro data methods and practice', Portuguese Economic Journal, 1(2):141-162.

Boone, P., 1996. 'Politics and the effectiveness of foreign aid', European Economic Review, $37(1): 51-55$.

Borensztein, E., De Gregorio, J., and Lee, J.-W., 1998. 'How does foreign direct investment affect economic growth?', Journal of International Economics, 45(1):115-135.

Bulir, A. and Hamann, A. J., 2008. 'Volatility of development aid: From the frying pan into the fire?', World Development, 36(10):2048-2066.

Burnside, C. and Dollar, D., 2000. 'Aid, policies, and growth', American Economic Review, 90(4):847-868.

Carr, D. L., Markusen, J. R., and Maskus, K. E., 2001. 'Estimating the knowledge capital model of the multinational enterprise', American Economic Review, 91(3):693-708.

Development Assistance Committee, 2003. Peer Review: Japan, Organisation for Economic Cooperation and Development, Paris.

—, 2007. DAC online, available at: www.oecd.org/dac/stats/idsonline.

Easterly, W., Levine, R., and Roodman, D., 2004. 'New data, new doubts: A comment on Burnside and Dollar's “Aid, policies, and growth" (2000)', American Economic Review, 94(3):774-780.

Egger, P., 2002. 'An econometric view on the estimation of gravity models and the calculation of trade potentials', World Economy, 25(2):297-312.

,- 2005 . 'Alternative techniques for estimation of cross-section gravity models', Review of International Economics, 13(5):881-892.

— and Winner, H., 2006. 'How corruption influences foreign direct investment: A panel data study', Economic Development and Cultural Change, 54(2):459-486.

Girma, S., 2005. 'Absorptive capacity and productivity spillovers from FDI: A threshold regression analysis', Oxford Bulletin of Economics and Statistics, 67(3):281-306.

Hansen, H. and Tarp, F., 2001. 'Aid and growth regressions', Journal of Development Economics, 64(2):547-570.

Harms, P. and Lutz, M., 2006. 'Aid, governance, and private foreign investment', Economic Journal, 116(513):773-790.

Japan Ministry of Economy, Industry and Trade (METI), 2006. The Interim Report of the Subcommittee on Economic Cooperation, Industrial Structure Council, Ministry of Economy, Trade and Industry, Tokyo. 
Javorcik, B. S., 2004. 'Does foreign direct investment increase the productivity of domestic firms? In search of spillovers through backward linkages', American Economic Review, 94(3):605-627.

Karakaplan, U. M., Neyapti, B., and Sayek, S., 2005. 'Aid and foreign direct investment: International evidence', Bilkent University Discussion Paper, No. 05-05.

Kaufmann, D., Kraay, A., and Mastruzzi, M., 2006. 'Governance matters V: Governance indicators for 1996-2005', SSRN Working Paper, No. 929549.

Kawai, M. and Takagi, S., 2004. 'Japan's official development assistance: Recent issues and future directions', Journal of International Development, 16(2):255-280.

Li, X. and Liu, X., 2005. 'Foreign direct investment and economic growth: An increasingly endogenous relationship', World Development, 33(3):393-407.

Markusen, J. R., 2002. Multinational Firms and the Theory of International Trade, MIT Press, Boston.

Mody, A., Razin, A., and Sadka, E., 2003. 'The role of information in driving FDI flows: Host-country transparency and source-country specialization', NBER Working Paper, No. 9662.

Organisation for Economic Cooperation and Development (OECD), 2004. Trends and Recent Developments in Foreign Direct Investment. OECD, Paris.

—, 2006. Investment for Development, OECD, Paris.

—, various years. Creditor Reporting System, OECD, Paris.

Available at:

//www.oecd.org/document/0/0,2340,en_2649_34447_37679488_1_1_1_1,00.html

Rajan, R. G. and Subramanian, A., 2005. 'Aid and growth: What does the cross-country evidence really show?', NBER Working Paper, No. 11513.

Roodman, D., 2007. 'How to do xtabond2: An introduction to "difference" and "system" GMM in Stata', Working Paper, No. 103, Center for Global Development.

Svensson, J., 2000. 'Foreign aid and rent-seeking', Journal of International Economics, 51(2):437461 .

Todo, Y. and Miyamoto, K., 2006. 'Knowledge spillovers from foreign direct investment and the role of R and D activities: Evidence from Indonesia', Economic Development and Cultural Change, 55(1):173-200.

United States Congress, 1997. The Role of Foreign Aid in Development, Congressional Budget Office, Washington D.C.

Wei, S.-J., 2000. 'How taxing is corruption on international investors?', Review of Economics and Statistics, 82(1):1-11.

Windmeijer, F., 2005. 'A finite sample correction for the variance of linear two-step GMM estimators', Journal of Econometrics, 126(1):25-51.

$\mathrm{Xu}, \mathrm{B} ., 2$ 2000. 'Multinational enterprises, technology diffusion, and host country productivity growth', Journal of Development Economics, 62(2):477-493.

Yao, S., 2006. 'On economic growth, FDI and exports in China', Applied Economics, 38(3): 339-351. 
Asia Pacific Economic Papers

Table 1. Summary Statistics

\begin{tabular}{|c|c|c|c|c|c|c|}
\hline & Description & $\begin{array}{c}\text { Number of } \\
\text { observations }\end{array}$ & Mean & $\begin{array}{l}\text { Standard } \\
\text { deviation }\end{array}$ & Min. & Max. \\
\hline InFDlij & $\begin{array}{l}\text { Log of FDI flows from } \\
\text { country i to j }\end{array}$ & 1384 & 11.03 & 2.16 & 2.66 & 16.40 \\
\hline $\ln \sum i \mathrm{AIDij}$ & $\begin{array}{l}\text { Log of total aid from all } \\
\text { countries to j }\end{array}$ & 1384 & 11.80 & 1.93 & 5.74 & 16.41 \\
\hline In $\sum i A D_{-} \mid N F i j$ & $\begin{array}{l}\text { Log of total aid for infrastructure } \\
\text { from all countries to } j\end{array}$ & 1384 & 11.52 & 2.04 & 0.00 & 15.19 \\
\hline In $\sum$ i AID_NonINFij & $\begin{array}{l}\text { Log of total aid for non- infras- } \\
\text { tructure from all countries to j }\end{array}$ & 1384 & 8.02 & 3.89 & 0.00 & 16.21 \\
\hline $\begin{array}{l}\text { InAIDij } \\
\text { InAID_INFij }\end{array}$ & $\begin{array}{l}\text { Log of aid from country i to } j \\
\text { Log of aid for infrastructure from }\end{array}$ & 1384 & 7.22 & 4.52 & 0.00 & 15.85 \\
\hline InAID_NonINFij & $\begin{array}{l}\text { country } i \text { to } j \\
\text { Log of aid for non- infrastructure } \\
\text { from country } i \text { to } j\end{array}$ & $\begin{array}{l}1384 \\
1384\end{array}$ & $\begin{array}{l}6.76 \\
2.43\end{array}$ & $\begin{array}{l}4.63 \\
3.90\end{array}$ & $\begin{array}{l}0.00 \\
0.00\end{array}$ & $\begin{array}{l}15.04 \\
15.85\end{array}$ \\
\hline InGDPi & Log of GDP of country i & 1384 & 21.46 & 0.68 & 20.77 & 23.01 \\
\hline InGDPj & Log of GDP of country j & 1384 & 17.87 & 1.71 & 10.67 & 20.99 \\
\hline InDISTij & Log of distance between $\mathrm{i}$ and $\mathrm{j}$ & 1384 & 8.53 & 0.90 & 5.63 & 9.82 \\
\hline SKDIFij & $\begin{array}{l}\text { Difference in the log of GDP per } \\
\text { capita between i and j } \\
\text { Index of the requlatory quality }\end{array}$ & $\begin{array}{c}1384 \\
793\end{array}$ & $\begin{array}{l}2.49 \\
421\end{array}$ & $\begin{array}{l}0.95 \\
0.62\end{array}$ & $\begin{array}{l}0.67 \\
129\end{array}$ & 5.94 \\
\hline Kaufmann2j & Sum of 6 indices of governance & 786 & $\begin{array}{l}4.21 \\
16.80\end{array}$ & 3.19 & $\begin{array}{l}1.29 \\
7.83\end{array}$ & 23.94 \\
\hline
\end{tabular}


No. 380, 2009

Table 2: Impact of Total Foreign Aid from All Donor Countries

\begin{tabular}{|c|c|c|c|c|c|c|}
\hline Dependent variable: & $\begin{array}{c}\text { pe amou } \\
\text { (1) } \\
\text { OLS }\end{array}$ & $\begin{array}{c}\text { ff FDI flov } \\
(2) \\
\text { GMM }\end{array}$ & $\begin{array}{c}\text { from cour } \\
\text { (3) } \\
\text { OLS }\end{array}$ & $\begin{array}{c}\mathrm{y} \text { i to cou } \\
(4) \\
\text { GMM }\end{array}$ & $\begin{array}{c}\text { (5) } \\
\text { OLS }\end{array}$ & $\begin{array}{c}(6) \\
\text { GMM }\end{array}$ \\
\hline InFDI & $\begin{array}{c}0.684 \\
(0.020)^{* *}\end{array}$ & $\begin{array}{c}0.398 \\
(0.058)^{\star *}\end{array}$ & $\begin{array}{c}0.634 \\
(0.029)^{\star *}\end{array}$ & $\begin{array}{c}0.330 \\
(0.067)^{\star *}\end{array}$ & $\begin{array}{c}0.630 \\
(0.029)^{\star *}\end{array}$ & $\begin{array}{c}0.324 \\
(0.067)^{\star *}\end{array}$ \\
\hline $\ln \sum i \mathrm{AIDij}$ & $\begin{array}{c}0.009 \\
(0.025)\end{array}$ & $\begin{array}{c}0.004 \\
(0.041)\end{array}$ & $\begin{array}{l}-0.159 \\
(0.148)\end{array}$ & $\begin{array}{l}-0.125 \\
(0.313)\end{array}$ & $\begin{array}{l}-0.197 \\
(0.178)\end{array}$ & $\begin{array}{l}-0.079 \\
(0.408)\end{array}$ \\
\hline In $\sum \mathrm{i} A I D i j$ * Kaufmann1j & & & $\begin{array}{c}0.009 \\
(0.008)\end{array}$ & $\begin{array}{c}0.011 \\
(0.018)\end{array}$ & & \\
\hline Kaufmann1j & & & $\begin{array}{l}-0.067 \\
(0.095)\end{array}$ & $\begin{array}{l}-0.078 \\
(0.194)\end{array}$ & & \\
\hline In $\sum \mathrm{i}$ AIDij * Kaufmann2j & & & & & $\begin{array}{c}0.043 \\
(0.041)\end{array}$ & $\begin{array}{c}0.029 \\
(0.093)\end{array}$ \\
\hline Kaufmann2j & & & & & $\begin{array}{l}-0.282 \\
(0.452)\end{array}$ & $\begin{array}{c}0.129 \\
(1.155)\end{array}$ \\
\hline InGDPi & $\begin{array}{c}0.960 \\
(1.266)\end{array}$ & $\begin{array}{c}4.779 \\
(1.898)^{*}\end{array}$ & $\begin{array}{c}1.330 \\
(2.158)\end{array}$ & $\begin{array}{c}2.393 \\
(2.743)\end{array}$ & $\begin{array}{c}1.390 \\
(2.150)\end{array}$ & $\begin{array}{c}3.390 \\
(2.596)\end{array}$ \\
\hline InGDPj & $\begin{array}{c}0.232 \\
(0.028)^{* *}\end{array}$ & $\begin{array}{c}0.473 \\
(0.104)^{\star *}\end{array}$ & $\begin{array}{c}0.337 \\
(0.047)^{\star *}\end{array}$ & $\begin{array}{c}0.610 \\
(0.135)^{\star *}\end{array}$ & $\begin{array}{c}0.340 \\
(0.045)^{\star *}\end{array}$ & $\begin{array}{c}0.546 \\
(0.111)^{\star *}\end{array}$ \\
\hline SKDIFij & $\begin{array}{l}-0.167 \\
(0.181)\end{array}$ & $\begin{array}{l}-1.095 \\
(0.499)^{*}\end{array}$ & $\begin{array}{c}0.056 \\
(0.307)\end{array}$ & $\begin{array}{l}-0.733 \\
(0.854)\end{array}$ & $\begin{array}{l}-0.006 \\
(0.286)\end{array}$ & $\begin{array}{l}-0.078 \\
(0.955)\end{array}$ \\
\hline SKDIFj2 & $\begin{array}{c}0.021 \\
(0.030)\end{array}$ & $\begin{array}{c}0.214 \\
(0.089)^{*}\end{array}$ & $\begin{array}{l}-0.010 \\
(0.052)\end{array}$ & $\begin{array}{c}0.137 \\
(0.162)\end{array}$ & $\begin{array}{c}0.008 \\
(0.049)\end{array}$ & $\begin{array}{c}0.027 \\
(0.174)\end{array}$ \\
\hline InDISTij & $\begin{array}{c}-0.139 \\
(0.038)^{* *}\end{array}$ & $\begin{array}{c}-0.289 \\
(0.070)^{\star *}\end{array}$ & $\begin{array}{c}-0.173 \\
(0.050)^{\star *}\end{array}$ & $\begin{array}{c}-0.341 \\
(0.081)^{\star *}\end{array}$ & $\begin{array}{c}-0.192 \\
(0.050)^{\star *}\end{array}$ & $\begin{array}{l}-0.317 \\
(0.080)^{* *}\end{array}$ \\
\hline $\begin{array}{l}\text { No. of observations } \\
\text { R-squared }\end{array}$ & $\begin{array}{l}1384 \\
0.737\end{array}$ & 1384 & $\begin{array}{c}786 \\
0.721\end{array}$ & 786 & $\begin{array}{c}793 \\
0.728\end{array}$ & 793 \\
\hline $\begin{array}{l}\text { Hansen J statistic } \\
\text { Arellano-Bond statistic }\end{array}$ & & $\begin{array}{l}0.165 \\
0.114\end{array}$ & & $\begin{array}{l}0.573 \\
0.202\end{array}$ & & $\begin{array}{l}0.700 \\
0.213\end{array}$ \\
\hline
\end{tabular}

Note: Standard errors are in parentheses. **, * , and + signify statistical significance at the $1 \%, 5 \%$, and $10 \%$ levels, respectively. Year dummies and donor-country dummies are included in all specifications. GMM estimation is based on the system GMM estimation developed by Blundell and Bond (1998). P values are reported for the Hansen J and Arellano-Bond statistics. Description of regressors are as follows: AIDij = foreign aid from country $i$ to country $j$; Kaufmann $l j=$ index of regulatory quality of country $j$ taken from Kaufmann et al. (2006); Kaufmann2ij = sum of 6 indices of governance of country $\mathrm{j}$ taken from Kaufmann et al. $(2006)$; GDPi $(j)=$ GDP of country $i(j) ;$ SKDIFij = measure of skill differences; DISTij = distance between country $\mathrm{i}$ and $\mathrm{j}$. All regressors are first lagged. 
Asia Pacific Economic Papers

Table 3: Differences between Aid for Infrastructure and Non-Infrastructure

\begin{tabular}{|c|c|c|c|c|c|c|}
\hline Dependent variable & the amou & of FDI flo & from cour & $\mathrm{y}$ i to cour & & \\
\hline & $(1)$ & $(2)$ & $(3)$ & $(4)$ & (5) & (6) \\
\hline & OLS & GMM & OLS & GMM & OLS & GMM \\
\hline Lagged InFDI & 0.685 & 0.393 & 0.685 & 0.387 & 0.685 & 0.386 \\
\hline & $(0.020)^{\star *}$ & $(0.053)^{\star *}$ & $(0.020)^{* *}$ & $(0.058)^{\star *}$ & $(0.020)^{\star *}$ & $(0.059)^{* *}$ \\
\hline In $\sum i A I D \_I N F i j$ & -0.008 & -0.013 & -0.009 & -0.002 & & \\
\hline & $(0.024)$ & $(0.032)$ & $(0.023)$ & $(0.034)$ & & \\
\hline In $\sum i$ AID_NonINFij & -0.001 & 0.025 & & & -0.002 & 0.026 \\
\hline & $(0.010)$ & $(0.017)$ & & & $(0.009)$ & $(0.016)$ \\
\hline InGDPi & 0.920 & 5.985 & 0.917 & 5.328 & 0.942 & 5.348 \\
\hline & $(1.268)$ & $(2.118)^{\star *}$ & $(1.267)$ & $(2.067)^{\star *}$ & $(1.265)$ & $(1.962)^{* *}$ \\
\hline InGDPj & 0.242 & 0.421 & 0.242 & 0.448 & 0.238 & 0.441 \\
\hline & $(0.029)^{* *}$ & $(0.080)^{\star *}$ & $(0.029)^{\star *}$ & $(0.095)^{\star *}$ & $(0.026)^{\star *}$ & $(0.086)^{* *}$ \\
\hline SKDIFij & -0.097 & -0.755 & -0.098 & -0.895 & -0.126 & -0.910 \\
\hline & $(0.185)$ & $(0.393)$ & $(0.185)$ & $(0.512)$ & $(0.161)$ & $(0.421)^{*}$ \\
\hline SKDIFj2 & 0.013 & 0.143 & 0.013 & 0.177 & 0.017 & 0.179 \\
\hline & $(0.031)$ & $(0.073)$ & $(0.031)$ & $(0.091)$ & $(0.028)$ & $(0.078)^{*}$ \\
\hline InDISTij & -0.134 & -0.241 & -0.134 & -0.278 & -0.136 & -0.281 \\
\hline & $(0.038)^{\star *}$ & $(0.067)^{\star *}$ & $(0.038)^{* *}$ & $(0.073)^{\star *}$ & $(0.037)^{\star \star}$ & $(0.066)^{* *}$ \\
\hline No. of observations & 1384 & 1384 & 1384 & 1384 & 1384 & 1384 \\
\hline R-squared & 0.737 & & 0.737 & & 0.737 & \\
\hline Hansen J statistic & & 0.291 & & 0.164 & & 0.254 \\
\hline Arellano-Bond statistic & & 0.126 & & 0.125 & & 0.132 \\
\hline
\end{tabular}

Note: Standard errors are in parentheses. ** * , and + signify statistical significance at the $1 \%, 5 \%$, and $10 \%$ levels, respectively. Year dummies and donor-country dummies are included in all specifications. GMM estimation is based on the system GMM estimation developed by Blundell and Bond (1998). P values are reported for the Hansen J and Arellano-Bond statistics. Description of regressors are as follows: AID_INFij $=$ aid for infrastructure from country i to $\mathrm{j}$; AID_NonINFij = aid for non-infrastructure from country $\mathrm{i}$ to $\mathrm{j}$; $\operatorname{GDPi}(j)=$ GDP of country $\mathrm{i}(\mathrm{j})$; SKDIFij = measure of skill differences; DISTij = distance between country $\mathrm{i}$ and $\mathrm{j}$. All regressors are first lagged. 
No. 380, 2009

Table 4: Impact of Foreign Aid on FDI from the Donor

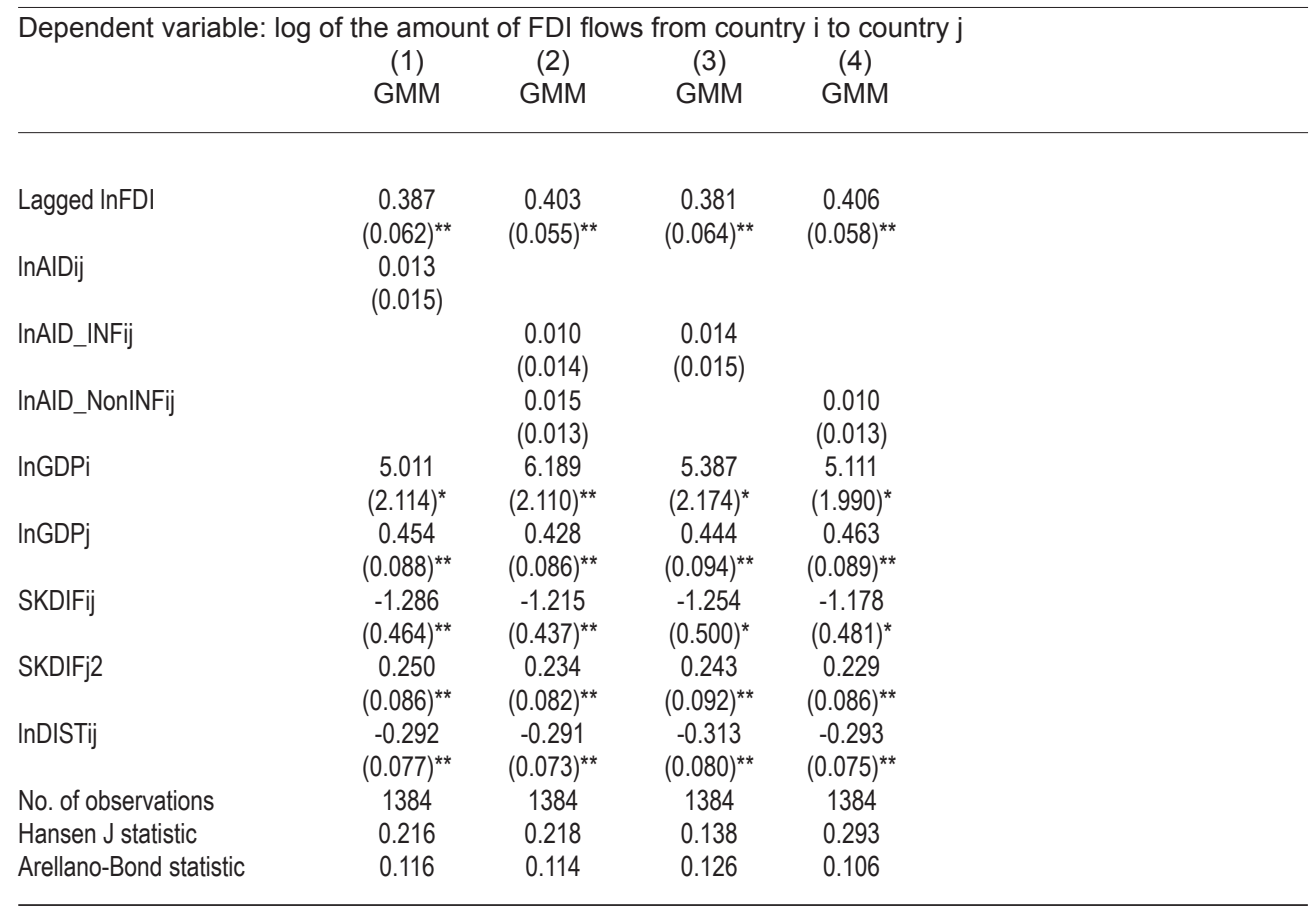

Note: Standard errors are in parentheses. ** * , and + signify statistical significance at the $1 \%, 5 \%$, and $10 \%$ levels, respectively. Year dummies and donor-country dummies are included in all specifications. GMM estimation is based on the system GMM estimation developed by Blundell and Bond (1998). P values are reported for the Hansen J and Arellano-Bond statistics. Description of regressors are as follows: AIDij = foreign aid from country $i$ to country $j$; AID_INFij = aid for infrastructure from country $i$ to $j$; AID_NonINFij = aid for non-infrastructure from country $i$ to $j ; \operatorname{GDPi}(j)=$ GDP of country $i(j)$; SKDIFij = measure of skill differences; DISTij = distance between country $\mathrm{i}$ and $\mathrm{j}$. All regressors are first lagged. 
Asia Pacific Economic Papers

Table 5: Difference in Impacts of Aid across Donor Countries

\begin{tabular}{|c|c|c|c|c|}
\hline Dependent variable & $\begin{array}{l}\text { he amol } \\
\text { (1) } \\
\text { GMM }\end{array}$ & $\begin{array}{l}\text { f FDI flo } \\
(2) \\
\text { GMM }\end{array}$ & $\begin{array}{l}\text { om cou } \\
\text { (3) } \\
\text { GMM }\end{array}$ & $\begin{array}{l}\text { i to country j } \\
(4) \\
\text { GMM }\end{array}$ \\
\hline InAIDFR, j & $\begin{array}{l}-0.017 \\
(0.016)\end{array}$ & & & \\
\hline InAIDGM, j & $\begin{array}{c}0.015 \\
(0.011)\end{array}$ & & & \\
\hline InAIDJP, j & $\begin{array}{c}0.012 \\
(0.013)\end{array}$ & & & \\
\hline InAIDUK, j & $\begin{array}{c}0.009 \\
(0.016)\end{array}$ & & & \\
\hline InAIDUS, j & $\begin{array}{l}-0.011 \\
(0.012)\end{array}$ & & & \\
\hline InAID_INFFR, j & & $\begin{array}{c}-0.019 \\
(0.019)\end{array}$ & $\begin{array}{l}-0.015 \\
(0.017)\end{array}$ & \\
\hline InAID_INFGM, j & & $\begin{array}{c}0.012 \\
(0.011)\end{array}$ & $\begin{array}{c}0.009 \\
(0.012)\end{array}$ & \\
\hline InAID_INFJP, j & & $\begin{array}{c}0.011 \\
(0.012)\end{array}$ & $\begin{array}{c}0.007 \\
(0.013)\end{array}$ & \\
\hline InAID_INFUK, j & & $\begin{array}{l}-0.002 \\
(0.015)\end{array}$ & $\begin{array}{c}0.002 \\
(0.016)\end{array}$ & \\
\hline InAID_INFUS, j & & $\begin{array}{c}-0.024 \\
(0.012)\end{array}$ & $\begin{array}{l}-0.017 \\
(0.014)\end{array}$ & \\
\hline InAID_NonINFFR, j & & $\begin{array}{l}-0.005 \\
(0.014)\end{array}$ & & $\begin{array}{l}-0.008 \\
(0.014)\end{array}$ \\
\hline InAID_NonINFGM, j & & $\begin{array}{l}-0.008 \\
(0.012)\end{array}$ & & $\begin{array}{l}-0.004 \\
(0.012)\end{array}$ \\
\hline InAID_NonINFJP, j & & $\begin{array}{c}0.009 \\
(0.013)\end{array}$ & & $\begin{array}{c}0.005 \\
(0.012)\end{array}$ \\
\hline InAID_NonINFUK, j & & $\begin{array}{l}-0.009 \\
(0.016)\end{array}$ & & $\begin{array}{l}-0.008 \\
(0.018)\end{array}$ \\
\hline InAID_NonINFUS, j & & $\begin{array}{c}-0.011 \\
(0.012)\end{array}$ & & $\begin{array}{c}-0.029 \\
(0.012)^{*}\end{array}$ \\
\hline No. of observations & 1384 & 1384 & 1384 & 1384 \\
\hline Hansen J statistic & 0.979 & 1.000 & 0.978 & 0.462 \\
\hline Arellano-Bond statistic & 0.117 & 0.056 & 0.119 & 0.037 \\
\hline \multicolumn{5}{|c|}{$\begin{array}{l}\text { Note: Standard errors are in parentheses. }{ }^{*} *{ }^{*} \text {, and }+ \text { signify statistical significance at the } 1 \%, 5 \% \text {, and } 10 \% \\
\text { levels, respectively. All control variables used in the benchmark estimation, year dummies, and donor-country } \\
\text { dummies are included in all specifications. GMM estimation is based on the system GMM estimation } \\
\text { developed by Blundell and Bond (1998). P values are reported for the Hansen J and Arellano-Bond } \\
\text { statistics. Description of regressors are as follows: AIDij = foreign aid from country i to country j; AID_INFij } \\
=\text { aid for infrastructure from country i to j; AID_NonINFij = aid for non-infrastructure from country i to } \\
\text { j; FR, GM JP, UK, and US, denote France, Germany, Japan, the United Kingdom, and the United States, } \\
\text { respectively. All regressors are first lagged. }\end{array}$} \\
\hline
\end{tabular}


No. 380,2009

Table 6: Difference in Vanguard Effects of Aid between Donor Countries

\begin{tabular}{|c|c|c|c|c|c|}
\hline Dependent variable & $\begin{array}{c}\text { he amol } \\
\text { (1) } \\
\text { GMM }\end{array}$ & of FDI flows from coun & $\begin{array}{l}\text { i to cour } \\
(2) \\
\text { GMM }\end{array}$ & $\begin{array}{l}\text { j } \\
\text { (3) } \\
\text { GMM }\end{array}$ & $\begin{array}{c}(4) \\
\text { GMM }\end{array}$ \\
\hline InAIDFR, j・FRi & $\begin{array}{l}-0.064 \\
(0.059)\end{array}$ & InAID_INFFR, j • FRi & $\begin{array}{l}-0.031 \\
(0.038)\end{array}$ & $\begin{array}{l}-0.030 \\
(0.043)\end{array}$ & \\
\hline InAIDGM, j•GMi & $\begin{array}{l}0.010 \\
(0.027)\end{array}$ & InAID_INFGM, j • GMi & $\begin{array}{l}-0.001 \\
(0.019)\end{array}$ & $\begin{array}{l}-0.004 \\
(0.021)\end{array}$ & \\
\hline InAIDJP, j •JPi & $\begin{array}{c}0.082 \\
(0.032)^{*}\end{array}$ & InAID_INFJP, j •JPi & $\begin{array}{c}0.074 \\
(0.028)^{\star *}\end{array}$ & $\begin{array}{c}0.064 \\
(0.025)^{*}\end{array}$ & \\
\hline InAIDUK, j•UKi & $\begin{array}{l}-0.006 \\
(0.044)\end{array}$ & InAID_INFUK, j • UKi & $\begin{array}{l}-0.015 \\
(0.050)\end{array}$ & $\begin{array}{c}0.007 \\
(0.045)\end{array}$ & \\
\hline InAIDUS, j • USi & $\begin{array}{l}-0.157 \\
(0.071)^{*}\end{array}$ & InAID_INFUS, j • USi & $\begin{array}{l}-0.011 \\
(0.056)\end{array}$ & $\begin{array}{l}-0.051 \\
(0.043)\end{array}$ & \\
\hline & & InAID_NonINFFR, j• FRi & $\begin{array}{c}0.033 \\
(0.025)\end{array}$ & & $\begin{array}{c}0.030 \\
(0.025)\end{array}$ \\
\hline & & InAID_NonINFGM, j • GMi & $\begin{array}{c}0.015 \\
(0.013)\end{array}$ & & $\begin{array}{c}0.026 \\
(0.014)\end{array}$ \\
\hline & & InAID_NonINFJP, j • JPi & $\begin{array}{l}0.038 \\
(0.038)\end{array}$ & & $\begin{array}{l}0.055 \\
(0.029)\end{array}$ \\
\hline & & InAID_NonINFUK, j•UKi & $\begin{array}{l}-0.005 \\
(0.058)\end{array}$ & & $\begin{array}{l}-0.001 \\
(0.049)\end{array}$ \\
\hline & & InAID_NonINFUS, $\mathrm{j} \cdot$ USi & $\begin{array}{l}-0.044 \\
(0.024)\end{array}$ & & $\begin{array}{l}-0.050 \\
(0.028)\end{array}$ \\
\hline No. of observations & 1384 & & 1384 & 1384 & 1384 \\
\hline Hansen J statistic & 1.000 & & 1.000 & 0.985 & 0.969 \\
\hline Arellano-Bond statistic & 0.161 & & 0.124 & 0.152 & 0.089 \\
\hline
\end{tabular}

Note: Standard errors are in parentheses. ${ }^{*}, *$, and + signify statistical significance at the $1 \%, 5 \%$, and $10 \%$ levels, respectively. All control variables used in the benchmark estimation, year dummies, and donor-country dummies are included in all specifications. GMM estimation is based on the system GMM estimation developed by Blundell and Bond (1998). P values are reported for the Hansen J and Arellano-Bond statistics. Description of regressors are as follows: AIDij = foreign aid from country i to country j; AID_INFij = aid for infrastructure from country $\mathrm{i}$ to $\mathrm{j}$; AID_NonINFij = aid for non-infrastructure from country $\mathrm{i}$ to j; FR, GM JP, UK, and US, denote France, Germany, Japan, the United Kingdom, and the United States, respectively; CTYi = a dummy variable that is one if source country $\mathrm{i}$ is CTY. Thus, for example, $\ln A I D F R, j \bullet F R j$ can be non-zero only when the home country of FDI in the left-hand side is France. All regressors are first lagged. 
Asia Pacific Economic Papers

Table 7: Results Using 3-Year Averages (1)

\begin{tabular}{|c|c|c|c|c|}
\hline \multicolumn{5}{|c|}{ Dependent variable: log of the amount of FDI stock from country $i$ to cour } \\
\hline & (1) & (2) & (3) & (4) \\
\hline & GMM & GMM & GMM & GMM \\
\hline \multicolumn{5}{|l|}{ Comparable } \\
\hline benchmark model & Table 2 (2) & Table 3 (2) & Table 4 (1) & Table 4 (2) \\
\hline Lagged InFDI & 0.403 & 0.414 & 0.406 & 0.376 \\
\hline & $(5.27)^{\star \star}$ & $(5.82)^{\star \star}$ & $(5.54)^{\star \star}$ & $(5.05)^{\star \star}$ \\
\hline $\ln \sum i \mathrm{AIDij}$ & $\begin{array}{l}0.084 \\
(0.69)\end{array}$ & & & \\
\hline In $\sum i$ AID_INFij & & $\begin{array}{l}0.026 \\
(0.23)\end{array}$ & & \\
\hline In $\sum i$ AID_NonINFij & & $\begin{array}{l}0.004 \\
(0.09)\end{array}$ & & \\
\hline InAIDij & & & $\begin{array}{l}0.004 \\
(0.09)\end{array}$ & \\
\hline In AID_INFij & & & & $\begin{array}{l}0.047 \\
(1.35)\end{array}$ \\
\hline In AID_NonINFij & & & & $\begin{array}{l}-0.046 \\
(1.52)\end{array}$ \\
\hline InGDPi & $\begin{array}{l}4.898 \\
(1.64)\end{array}$ & $\begin{array}{l}5.296 \\
(1.87)\end{array}$ & $\begin{array}{l}4.348 \\
(1.45)\end{array}$ & $\begin{array}{c}5.106 \\
(2.00)^{*}\end{array}$ \\
\hline InGDPj & $\begin{array}{c}0.408 \\
(2.95)^{* *}\end{array}$ & $\begin{array}{c}0.444 \\
(3.56)^{* *}\end{array}$ & $\begin{array}{c}0.518 \\
(3.81)^{* *}\end{array}$ & $\begin{array}{c}0.503 \\
(3.59)^{\star *}\end{array}$ \\
\hline SKDIFij & $\begin{array}{l}-0.970 \\
(1.06)\end{array}$ & $\begin{array}{l}-0.977 \\
(1.08)\end{array}$ & $\begin{array}{l}-1.580 \\
(1.74)\end{array}$ & $\begin{array}{r}-1.451 \\
(1.66)\end{array}$ \\
\hline SKDIFj2 & $\begin{array}{l}0.186 \\
(1.08)\end{array}$ & $\begin{array}{l}0.197 \\
(1.13)\end{array}$ & $\begin{array}{l}0.296 \\
(1.61)\end{array}$ & $\begin{array}{l}0.277 \\
(1.51)\end{array}$ \\
\hline InDISTij & $\begin{array}{c}-0.321 \\
(3.87)^{\star *}\end{array}$ & $\begin{array}{c}-0.295 \\
(3.50)^{* *}\end{array}$ & $\begin{array}{c}-0.322 \\
(3.64)^{\star \star}\end{array}$ & $\begin{array}{c}-0.364 \\
(4.42)^{\star *}\end{array}$ \\
\hline No. of observations & 458 & 458 & 458 & 458 \\
\hline Hansen J statistic & 0.495 & 0.571 & 0.590 & 0.593 \\
\hline Arellano-Bond statistic & 0.779 & 0.822 & 0.815 & 0.742 \\
\hline
\end{tabular}

Note: Standard errors are in parentheses. ** * , and + signify statistical significance at the $1 \%, 5 \%$, and $10 \%$ levels, respectively. All control variables used in the benchmark estimation, year dummies, and donor-country dummies are included in all specifications. GMM estimation is based on the system GMM estimation developed by Blundell and Bond (1998). P values are reported for the Hansen J and Arellano-Bond statistics. Description of regressors are as follows: AIDij = stock of aid from country i to j. 
No. 380, 2009

Table 8: Results Using 3-Year Averages (2)

\begin{tabular}{|c|c|c|c|c|c|}
\hline Dependent variable & $\begin{array}{c}\text { f the amoun } \\
\text { (1) } \\
\text { GMM }\end{array}$ & $\begin{array}{c}\text { of FDI stoc } \\
(2) \\
\text { GMM }\end{array}$ & from country i to coun & $\begin{array}{c}(3) \\
\text { GMM }\end{array}$ & $\begin{array}{c}(4) \\
\text { GMM }\end{array}$ \\
\hline \multicolumn{6}{|l|}{ Comparable } \\
\hline benchmark model & Table $5(1)$ & Table 5 (3) & Comparable & & \\
\hline benchmark model & Table 6 (3) & Table 6 (4) & & & \\
\hline Lagged InFDI & $\begin{array}{c}0.395 \\
(5.09)^{* *}\end{array}$ & $\begin{array}{c}0.457 \\
(6.96)^{* *}\end{array}$ & Lagged InFDI & $\begin{array}{c}0.361 \\
(5.08)^{\star *}\end{array}$ & $\begin{array}{c}0.372 \\
(4.51)^{\star *}\end{array}$ \\
\hline InAIDFR, j & $\begin{array}{l}-0.035 \\
(1.17)\end{array}$ & & InAID_INFFR,j • FRj & $\begin{array}{l}0.038 \\
(0.33)\end{array}$ & \\
\hline InAIDGM, j & $\begin{array}{l}0.017 \\
(0.73)\end{array}$ & & InAID_INFGM,j • GMj & $\begin{array}{l}-0.023 \\
(0.55)\end{array}$ & \\
\hline InAIDJP, j & $\begin{array}{l}0.032 \\
(1.23)\end{array}$ & & InAID_INFJP,j • JPj & $\begin{array}{c}0.117 \\
(2.50)^{*}\end{array}$ & \\
\hline InAIDUK, j & $\begin{array}{l}0.041 \\
(1.17)\end{array}$ & & InAID_INFUK,j • UKj & $\begin{array}{c}0.179 \\
(2.44)^{*}\end{array}$ & \\
\hline InAIDUS, j & $\begin{array}{l}-0.012 \\
(0.39)\end{array}$ & & InAID_INFUS,j • USj & $\begin{array}{r}-0.087 \\
(0.88)\end{array}$ & \\
\hline InAID_INFFR, j & & $\begin{array}{l}-0.020 \\
(0.95)\end{array}$ & InAID_NonINFFR, j • FRi & & $\begin{array}{l}-0.044 \\
(0.92)\end{array}$ \\
\hline InAID_INFGM, j & & $\begin{array}{l}-0.026 \\
(1.11)\end{array}$ & InAID_NonINFGM, j • GMi & & $\begin{array}{l}-0.005 \\
(0.08)\end{array}$ \\
\hline InAID_INFJP, j & & $\begin{array}{l}0.020 \\
(0.94)\end{array}$ & InAID_NonINFJP, j • JPi & & $\begin{array}{l}-0.044 \\
(1.07)\end{array}$ \\
\hline InAID_INFUK, j & & $\begin{array}{l}-0.004 \\
(0.13)\end{array}$ & InAID_NonINFUK, j•UKi & & $\begin{array}{l}0.016 \\
(0.19)\end{array}$ \\
\hline InAID_INFUS, j & & $\begin{array}{l}-0.024 \\
(1.17)\end{array}$ & InAID_NonINFUS, j • USi & & $\begin{array}{l}-0.076 \\
(1.02)\end{array}$ \\
\hline InGDPi & $\begin{array}{l}5.807 \\
(2.08)^{*}\end{array}$ & $\begin{array}{c}5.409 \\
(2.11)^{*}\end{array}$ & InGDPi & $\begin{array}{l}4.394 \\
(1.79)\end{array}$ & $\begin{array}{c}5.547 \\
(2.46)^{*}\end{array}$ \\
\hline InGDPj & $\begin{array}{c}0.311 \\
(2.61)^{\star *}\end{array}$ & $\begin{array}{c}0.385 \\
(3.85)^{\star *}\end{array}$ & InGDPj & $\begin{array}{c}0.452 \\
(3.83)^{\star *}\end{array}$ & $\begin{array}{c}0.411 \\
(2.89)^{* *}\end{array}$ \\
\hline SKDIFij & $\begin{array}{l}-1.564 \\
(1.67)\end{array}$ & $\begin{array}{l}-0.483 \\
(0.74)\end{array}$ & SKDIFij & $\begin{array}{l}-1.640 \\
(2.33)^{*}\end{array}$ & $\begin{array}{r}-0.861 \\
(1.24)\end{array}$ \\
\hline SKDIFj2 & $\begin{array}{l}0.273 \\
(1.65)\end{array}$ & $\begin{array}{l}0.103 \\
(0.85)\end{array}$ & SKDIFj2 & $\begin{array}{c}0.313 \\
(2.26)^{*}\end{array}$ & $\begin{array}{l}0.169 \\
(1.27)\end{array}$ \\
\hline InDISTij & $\begin{array}{l}-0.348 \\
(3.93)^{\star *}\end{array}$ & $\begin{array}{c}-0.293 \\
(4.32)^{\star *}\end{array}$ & InDISTij & $\begin{array}{l}-0.368 \\
(4.71)^{\star \star}\end{array}$ & $\begin{array}{l}-0.337 \\
(4.09)^{\star *}\end{array}$ \\
\hline No. of observations & 458 & 458 & No. of observations & 458 & 458 \\
\hline Hansen J statistic & 0.199 & 0.423 & Hansen J statistic & 0.780 & 0.475 \\
\hline Arellano-Bond statistic & 0.847 & 0.703 & Arellano-Bond statistic & 0.805 & 0.932 \\
\hline
\end{tabular}

Note: Standard errors are in parentheses. ** * , and + signify statistical significance at the $1 \%, 5 \%$, and $10 \%$ levels, respectively. All control variables used in the benchmark estimation, year dummies, and donor-country dummies are included in all specifications. GMM estimation is based on the system GMM estimation developed by Blundell and Bond (1998). P values are reported for the Hansen J and Arellano-Bond statistics. Description of regressors are as follows: AIDij = stock of aid from country i to j; FR, GM JP, UK, and US, denote France, Germany, Japan, the United Kingdom, and the United States, respectively; CTYi = a dummy variable that is one if source country $i$ is CTY. 
Asia Pacific Economic Papers

Table 9: Results Using the LDC Sample

Dependent variable: log of the amount of FDI stock from country i to country $j$

(1)

(2)

GMM

GMM

\begin{tabular}{|c|c|c|c|}
\hline \multicolumn{4}{|l|}{ Comparable } \\
\hline benchmark model & Table 5 (1) & & Table 6 (1) \\
\hline InAIDFR, j & $\begin{array}{l}-0.036 \\
(0.023)\end{array}$ & InAIDFR,j • FRj & $\begin{array}{l}-0.043 \\
(0.058)\end{array}$ \\
\hline InAIDGM, j & $\begin{array}{c}0.004 \\
(0.013)\end{array}$ & InAIDGM,j • GMj & $\begin{array}{c}(0.058) \\
0.014 \\
(0.018)\end{array}$ \\
\hline InAIDJP, j & $\begin{array}{c}0.031 \\
(0.020)\end{array}$ & $\operatorname{InAIDJP,j} \cdot J P j$ & $\begin{array}{c}0.157 \\
(0.066)^{*}\end{array}$ \\
\hline InAIDUK, j & $\begin{array}{c}0.004 \\
(0.019)\end{array}$ & InAIDUK,j • UKj & $\begin{array}{c}0.027 \\
(0.050)\end{array}$ \\
\hline InAIDUS, j & $\begin{array}{l}-0.029 \\
(0.018)\end{array}$ & InAIDUS,j • USj & $\begin{array}{l}-0.131 \\
(0.088)\end{array}$ \\
\hline No. of observations & 924 & No. of observations & 924 \\
\hline Hansen J statistic & 1.000 & Hansen J statistic & 1.000 \\
\hline Arellano-Bond statistic & 0.327 & Arellano-Bond statistic & 0.413 \\
\hline \multicolumn{4}{|c|}{$\begin{array}{l}\text { Note: Standard errors are in parentheses. **, * and }+ \text { signify statistical significance at the } 1 \%, 5 \% \text {, and } 10 \% \\
\text { levels, respectively. All control variables used in the benchmark estimation, year dummies, and donor-country } \\
\text { dummies are included in all specifications. GMM estimation is based on the system GMM estimation } \\
\text { developed by Blundell and Bond (1998). P values are reported for the Hansen J and Arellano-Bond } \\
\text { statistics. Description of regressors are as follows: AIDij = stock of aid from country i to j; FR, GM JP, UK, } \\
\text { and US, denote France, Germany, Japan, the United Kingdom, and the United States, respectively; CTYi = a } \\
\text { dummy variable that is one if source country i is CTY. }\end{array}$} \\
\hline
\end{tabular}


No. 380, 2009

Appendix Table: List of Country-Pairs

\begin{tabular}{|c|c|c|c|c|c|c|}
\hline & France & Germany & Japan & $\begin{array}{c}\text { United } \\
\text { Kingdom }\end{array}$ & $\begin{array}{l}\text { United } \\
\text { States }\end{array}$ & Total \\
\hline Albania & 6 & 5 & 0 & 0 & 0 & 11 \\
\hline Algeria & 6 & 1 & 0 & 0 & 0 & 7 \\
\hline Angola & 1 & 2 & 0 & 0 & 0 & 3 \\
\hline Antigua and Barbuda & 0 & 0 & 0 & 0 & 1 & 1 \\
\hline Argentina & 12 & 6 & 13 & 13 & 11 & 55 \\
\hline Azerbaijan & 0 & 5 & 0 & 0 & 0 & 5 \\
\hline Bahrain & 0 & 1 & 0 & 0 & 0 & 1 \\
\hline Belarus & 0 & 8 & 0 & 0 & 0 & 8 \\
\hline Benin & 1 & 0 & 0 & 0 & 0 & 1 \\
\hline Bolivia & 5 & 4 & 0 & 0 & 0 & 9 \\
\hline Bosnia and Herzegovina & 0 & 2 & 0 & 0 & 0 & 2 \\
\hline Botswana & 0 & 1 & 0 & 0 & 0 & 1 \\
\hline Brazil & 6 & 8 & 13 & 13 & 12 & 52 \\
\hline Bulgaria & 10 & 10 & 0 & 3 & 0 & 23 \\
\hline Burkina Faso & 1 & 0 & 0 & 0 & 0 & 1 \\
\hline Cambodia & 3 & 0 & 0 & 0 & 0 & 3 \\
\hline Cameroon & 2 & 0 & 0 & 0 & 0 & 2 \\
\hline Chad & 4 & 0 & 0 & 0 & 0 & 4 \\
\hline Chile & 4 & 6 & 13 & 6 & 12 & 41 \\
\hline China & 10 & 13 & 13 & 9 & 13 & 58 \\
\hline Colombia & 3 & 6 & 1 & 6 & 5 & 21 \\
\hline Comoros & 1 & 0 & 0 & 0 & 0 & 1 \\
\hline Congo & 2 & 5 & 0 & 0 & 0 & 7 \\
\hline Congo, Dem. Rep. & 1 & 0 & 0 & 0 & 0 & 1 \\
\hline Costa Rica & 1 & 6 & 0 & 0 & 0 & 7 \\
\hline Cote d'Ivoire & 4 & 1 & 0 & 0 & 0 & 5 \\
\hline Croatia & 6 & 9 & 0 & 0 & 0 & 15 \\
\hline Czech Republic & 9 & 8 & 9 & 5 & 2 & 33 \\
\hline Dominica & 0 & 7 & 0 & 0 & 1 & 8 \\
\hline Ecuador & 7 & 13 & 0 & 0 & 1 & 21 \\
\hline Egypt & 13 & 4 & 1 & 5 & 1 & 24 \\
\hline El Salvador & 0 & 6 & 0 & 0 & 0 & 6 \\
\hline Estonia & 2 & 6 & 0 & 0 & 0 & 8 \\
\hline Ethiopia & 0 & 0 & 0 & 0 & 1 & 1 \\
\hline Gabon & 7 & 0 & 0 & 0 & 0 & 7 \\
\hline Ghana & 0 & 3 & 0 & 0 & 0 & 3 \\
\hline Grenada & 0 & 1 & 0 & 0 & 0 & 1 \\
\hline Guatemala & 0 & 8 & 0 & 0 & 0 & 8 \\
\hline Guinea & 5 & 0 & 0 & 0 & 0 & 5 \\
\hline Guinea-Bissau & 2 & 0 & 0 & 0 & 0 & 2 \\
\hline Guyana & 1 & 0 & 0 & 0 & 0 & 1 \\
\hline Haiti & 2 & 0 & 0 & 0 & 0 & 2 \\
\hline Hungary & 7 & 9 & 10 & 6 & 1 & 33 \\
\hline Indonesia & 10 & 7 & 13 & 1 & 10 & 41 \\
\hline India & 13 & 10 & 13 & 10 & 10 & 56 \\
\hline Iran & 3 & 0 & 0 & 0 & 1 & 4 \\
\hline Jamaica & 0 & 6 & 0 & 0 & 1 & 7 \\
\hline Jordan & 0 & 5 & 0 & 0 & 0 & 5 \\
\hline Kazakhstan & 1 & 6 & 0 & 0 & 0 & 7 \\
\hline Latvia & 2 & 6 & 0 & 0 & 0 & 8 \\
\hline Lebanon & 7 & 7 & 0 & 0 & 0 & 14 \\
\hline Liberia & 3 & 4 & 3 & 0 & 0 & 10 \\
\hline Lithuania & 6 & 8 & 0 & 0 & 0 & 14 \\
\hline Macedonia & 0 & 6 & 0 & 0 & 0 & 6 \\
\hline Madagascar & 2 & 0 & 0 & 0 & 0 & 2 \\
\hline
\end{tabular}


Asia Pacific Economic Papers

Appendix Table: List of Country-Pairs (continued)

\begin{tabular}{|c|c|c|c|c|c|c|}
\hline & France & Germany & Japan & $\begin{array}{c}\text { United } \\
\text { Kingdom }\end{array}$ & $\begin{array}{l}\text { United } \\
\text { States }\end{array}$ & Total \\
\hline Malawi & 0 & 1 & 0 & 0 & 0 & 1 \\
\hline Malaysia & 7 & 9 & 13 & 8 & 5 & 42 \\
\hline Mali & 2 & 0 & 0 & 0 & 0 & 2 \\
\hline Mauritius & 8 & 3 & 0 & 0 & 0 & 11 \\
\hline Mexico & 13 & 7 & 13 & 9 & 13 & 55 \\
\hline Moldova & 0 & 5 & 0 & 0 & 0 & 5 \\
\hline Morocco & 6 & 8 & 0 & 1 & 2 & 17 \\
\hline Namibia & 0 & 11 & 0 & 0 & 0 & 11 \\
\hline Nicaragua & 0 & 3 & 0 & 0 & 0 & 3 \\
\hline Nigeria & 0 & 4 & 0 & 0 & 0 & 4 \\
\hline Oman & 3 & 3 & 0 & 0 & 0 & 6 \\
\hline Pakistan & 8 & 8 & 0 & 0 & 0 & 16 \\
\hline Panama & 2 & 5 & 0 & 0 & 1 & 8 \\
\hline Paraguay & 4 & 10 & 0 & 0 & 1 & 15 \\
\hline Peru & 3 & 3 & 0 & 0 & 0 & 6 \\
\hline Philippines & 7 & 10 & 13 & 10 & 9 & 49 \\
\hline Poland & 7 & 11 & 11 & 9 & 4 & 42 \\
\hline Romania & 9 & 7 & 3 & 0 & 1 & 20 \\
\hline Russia & 9 & 9 & 9 & 5 & 0 & 32 \\
\hline Sao Tome and Principe & 0 & 1 & 0 & 0 & 0 & 1 \\
\hline Senegal & 4 & 3 & 0 & 0 & 0 & 7 \\
\hline Serbia and Montenegro & 0 & 1 & 0 & 0 & 0 & 1 \\
\hline Seychelles & 0 & 3 & 0 & 0 & 0 & 3 \\
\hline Slovak Republic & 5 & 8 & 0 & 3 & 0 & 16 \\
\hline Slovenia & 7 & 7 & 0 & 2 & 1 & 17 \\
\hline South Africa & 8 & 5 & 5 & 4 & 5 & 27 \\
\hline South Korea & 12 & 10 & 13 & 7 & 10 & 52 \\
\hline Sri Lanka & 0 & 3 & 0 & 0 & 0 & 3 \\
\hline Suriname & 0 & 0 & 0 & 0 & 1 & 1 \\
\hline Syria & 4 & 4 & 0 & 0 & 0 & 8 \\
\hline Thailand & 10 & 12 & 13 & 12 & 10 & 57 \\
\hline Trinidad and Tobago & 1 & 6 & 0 & 0 & 0 & 7 \\
\hline Tunisia & 0 & 1 & 0 & 0 & 0 & 1 \\
\hline Turkey & 13 & 12 & 13 & 12 & 13 & 63 \\
\hline Ukraine & 5 & 6 & 0 & 3 & 0 & 14 \\
\hline Uruguay & 8 & 8 & 0 & 0 & 1 & 17 \\
\hline Uzbekistan & 0 & 4 & 0 & 0 & 0 & 4 \\
\hline Vanuatu & 1 & 0 & 0 & 0 & 0 & 1 \\
\hline Venezuela & 6 & 10 & 6 & 4 & 10 & 36 \\
\hline Vietnam & 4 & 4 & 0 & 0 & 0 & 8 \\
\hline Yemen & 6 & 3 & 0 & 0 & 0 & 9 \\
\hline Zambia & 1 & 0 & 0 & 0 & 0 & 1 \\
\hline Zimbabwe & 0 & 3 & 0 & 0 & 0 & 3 \\
\hline Total & 374 & 460 & 214 & 166 & 170 & 1,384 \\
\hline
\end{tabular}

Note: The number for each country pair represents the number of observations for the country pair during the 13-year period from 1990 to 2002. 


\section{Notes}

$\dagger \quad$ Ministry of Finance.

$\ddagger \quad$ Corresponding author. Graduate School of Frontier Sciences, the University of Tokyo. Email: yastodo@k.u-tokyo.ac.jp. URL: http://park.itc.u-tokyo.ac.jp/yastodo/.

1 These two examples are cited in Harms and Lutz (2006).

2 Harms and Lutz (2006) and Karakaplan, Neyapti, and Sayek (2005) both use governance indices constructed by an earlier version of Kaufmann et al. (2006). A notable difference between these two studies is the time period covered: 1988-1999 in Harms and Lutz (2006) and 1960-2004 in Karakaplan, Neyapti, and Sayek (2005).

Our finding is consistent with Blaise (2005) who finds that Japanese aid in China has a positive and significant impact on the locational choice of Japanese private investors in China, using province-level data for China. However, since Blaise (2005) does not examine the impact of Japanese aid on FDI from other countries, it is not clear from Blaise (2005) whether Japanese aid has a vanguard effect or other effects.

The horizontal model of multinational enterprises typically explains FDI between similarly endowed countries (that is, between developed countries), but it can be applied to FDI from a developed country to a less developed country when the less developed country imposes trade restrictions so that export from the developed country to the less developed country may not be possible.

Most studies in the literature, such as Bergstrand and Egger (2007), Harms and Lutz (2006), Karakaplan, Neyapti, and Sayek (2005), and Wei (2000), use FDI inflows in gravity models of FDI, while some, such as Egger and Winner (2006), use FDI stocks. We follow the former specification, but in a robustness check not shown in this paper, we also regress FDI stocks on stocks of foreign aid and obtain similar results.

As we will explain later, we employ the system generalised method of moments (GMM) estimation developed by Blundell and Bond (1998). Since we estimate the equation without fixed effects in addition to the first-differenced equation in the system GMM estimation, we can estimate the effect of distance, even after controlling for fixed effects.

Other possible control variables include a measure of country j's quality of governance that relates to FDI inflows employed in Egger and Winner (2006), a measure of openness of country j employed in Mody, Razin, and Sadka (2003), and a dummy variable for sharing a common official language employed in Bergstrand and Egger (2007). However, since we find that the effects of these variables are not statistically significant in most specifications, we do not use them for estimation.

Svensson (2000) argues that foreign aid and windfalls are on average associated with higher corruption in countries which suffer from powerful competing social groups.

9 The authors would like to thank an anonymous referee for pointing out the financing effect and the Dutch-disease effect.

10 System GMM is estimated by using a Stata command of xtabond 2 developed by David Roodman.

11 When we will later examine the effect of aid from each donor country, we will use aid from each donor as a separate regressor. Therefore, if we have many donors in our sample, we will have many regressors and thus many instruments in our system GMM estimation. As Roodman (2007) argues and Section 4.2 briefly explains, many instruments in the system GMM estimation lead to a weak test for over-identification. Therefore, we limit source countries to five.

12 The complete list of the country pairs used in this paper is shown in Appendix Table. 
13 The use of logs implies that we drop observations when FDI inflows are negative due to sales of existing MNEs. As a robustness check, we used FDI inflows without taking a log as the dependent variable and obtained results similar to those using logs.

14 In the data-set, OECD defines direct investment as the sum of new capital outflows and reinvested earnings. Direct investment comprises financing by an entity resident in a reporting country which has the objective of obtaining or retaining a lasting interest in an entity resident in an aid recipient country. 'Lasting interest' implies a long-term relationship where the direct investor has a significant influence on the management of the enterprise, reflected by ownership of at least 10 per cent of the shares of the enterprise, or the equivalent in voting power or other means of control.

The unit of FDI variables is 1,000 U.S. dollars.

CRS contains detailed information on individual aid activities of most of the 23 members of the OECD's DAC as well as those of multilateral development banks and United Nations agencies. The whole data-set is available at: http://www. oecd.org/document/0/0,2340,en_2649_34447_37679488_l_1_1_l,00.html (last accessed on December 12, 2008).

17 Using the disbursed amount of aid would be more appropriate than using its committed amount. However, according to CRS User's Guide available on the web site of the CRS (see the previous footnote), 'Data on the amounts disbursed each year are available at the activity level for some, but not all, donors. Consequently, most analyses have to be undertaken on a commitment basis.' Due to this data limitation, we use the committed amount of aid.

18 Note that although donor countries other than the top five donors are excluded from the sample, aid from all donor countries, rather than aid from the top five donors, is aggregated to construct $\sum$ i AIDijt.

19 The unit of aid variables is 1,000 U.S. dollars.

20 Instead of GDP per capita, we could use the level of education measured, for example, by the secondary enrolment ratio. However, we do not employ this due to the data limitations.

21 Since the governance indicators of Kaufmann and Kraay (2006) are available only for 1996, 1998,2000 , and 2002, we manipulate data for 1997, 1999, and 2001 from the average of the nearest two years and data for 1995 from the trend during the period 1996-1998.

22 We include the square term, since SKDIF does not have any significant effect when included alone in estimation while both SKDIF and its square have a highly significant effect when included together.

23 We also break down 'infrastructure' into social infrastructure, economic infrastructure, production, and multi-sector. However, we find no significant effect of either sub-category of aid for infrastructure.

24 The correlation coefficient of the two is 0.56 .

25 Harms and Lutz (2006) and Karakaplan, Neyapti, and Sayek (2005) also find no significant effect of aid on FDI in most specifications in which the interaction term between aid and governance is not included.

26 Since the effect of US non-infrastructure aid is negative and significant at the 10-per cent level in columns 2 and 4 of Table 6, one may conclude that non-infrastructure aid of the United States discourages aid. A possible reason for the weak evidence of a negative effect of US non-infrastructure aid is that non-infrastructure aid from the United States, mostly aid for debt relief, may be regarded as a bad signal by foreign investors.

We do not present the results for the sake of brevity. 


\section{Previous Asia Pacific Economic Papers}

379 Rain, Elections and Money: The Impact of Voter Turnout on Distributive Policy Outcomes in Japan Yusaku Horiuchi and Jun Saito, 2009

378 Japanese FDI in China: determinants and performance Shiro Armstrong, 2009

377 Expansion Abroad and Jobs at Home: Evidence from Japanese Multinational Enterprises Nobuaki Yamashita and Kyoji Fukao, 2009

376 Should Australia Encourage Developing Countries to Adopt Competition Laws? Henry Ergas, 2008

375 Will New Trends in Foreign Direct Investment Change the Structure of Intra-industry Trade between China and Japan?

Tao Tao, 2008

374 Competition Policy in ASEAN: Case studies Johannah Branson, 2008

373 Can the New Antimonopoly Act Change the Japanese Business Community? The 2005 Amendment to Antimonopoly Act and Corporate Compliance.

Kazukiyo Onishi, 2008

372 Immunising future trade against protectionists: preventing the emergence of more sensitive sectors Andrew Elek, 2008

371 Tax law asymmetries and income shifting: evidence from Japanese Capital KEIRETSU Kazuki Onji and David Vera, 2008

370 The response of firms to eligibility thresholds: evidence from the Japanese value-added tax Kazuki Onji, 2008

369 China and East Asian Energy: Prospects and Issues Vol. 1 \& 11

Peter Drysdale, Kejun Jiang and Dominic Meagher, 2008

368 Measuring trade and trade potential Shiro Armstrong, 2007

367 APEC and infectious disease: meeting the challenge Joel Gilbourd, 2007

366 The flow of funds through a government - A case study on Japan Jun Ikeda, 2007

365 The puzzle of small farming in Japan Yoshibisa Godo, 2007

364 How should one evaluate fiscal conditions? A study based on the comparison between Japan and Australia Jun Ikeda, 2007

363 Political institutions and distributive politics in Japan: getting along with the opposition Yusaku Horiuchi, 2007

362 Negotiating the Australia-Japan basic treaty of friendship and cooperation: reflections and afterthoughts Garry Woodard, Moreen Dee and Max Suich, 2007

361 China and East Asian energy: prospects and issues Vol. 1 Peter Drysdale, Kejun Jiang and Dominic Meagher, 2007

360 Agriculture and political reform in Japan: the Koizumi legacy Aurelia George Mulgan, 2006

359 Nothing new in the (north) east? Interpreting the rhetoric and reality of Japanese corporate governance Luke Nottage, 2006 
Asia Pacific Economic Papers

Annual subscription rate for up to twelve issues:

Individuals A $\$ 65.00$ (includes GST) A \$60 (overseas)

Institutions A $\$ 10.00$ (includes GST) A 100 (overseas)

Cost for single issues:

A $\$ 16.50$ (includes GST) A $\$ 15.00$ (overseas)

A $\$ 10.00$ (Students)

No postage required within Australia

Available from:

Centre Administrator

Australia-Japan Research Centre

Crawford School of Economics and Management

ANU College of Asia and the Pacific

The Australian National University

Canberra ACT 0200, Australia

Facsimile: (61 2) 61250767

Telephone: (61 2) 61253780

Email: ajrc@anu.edu.au

URL: http:/www.crawford.anu.edu.au 